\title{
LA NOVELA Y LA POÉTICA FEMENINA
}

\author{
M.a del Carmen Bobes Naves
}

(Universidad de Oviedo)

\section{PRESENTACIÓN}

La literatura escrita por mujeres ha existido con mayor o menor profusión a lo largo de los siglos. Desde Safo de Lesbos en la antigüedad clásica hasta los tiempos actuales ha habido poetisas, novelistas $\mathrm{y}$, quizá en menor proporción, dramaturgas. Lo mismo podría decirse de la producción crítica literaria: probablemente siempre ha habido, o ha podido haber, críticas y teóricas de la literatura, y, desde luego, siempre ha habido lectoras que han podido hacer interpretaciones y tener opiniones sobre las obras literarias.

Es indudable, por otra parte, que en el conjunto de la producción literaria de todos los tiempos, la participación de la mujer en la creación literaria es mucho menor que la del hombre, aunque en la actualidad esa desproporción se está corrigiendo y, también hasta tiempos actuales, las teorizaciones críticas femeninas son escasas y puntuales. 
Se da otro hecho, que no queremos pasar por alto, y es que en otras artes la aportación de la mujer es aún más escasa y faltan totalmente teorizaciones femeninas destacables sobre las artes. Quizá es la creación literaria y la teoría sobre ella el campo donde hay más participación de la mujer, por lo menos hasta ahora.

Las causas de esta situación pueden ser de tipo personal, familiar o social: la arquitectura tiene unas exigencias sociales de formación y de ejercicio que conceden a la mujer escasas oportunidades; la escultura tiene alguna posibilidad más y efectivamente hay alguna escultora; en la pintura, al ser una de las artes que no requieren para su producción esa dimensión social, hubo siempre mujeres pintoras, autodidactas generalmente, y algunas alcanzaron fama y nivel artístico. En todo caso, sea cual sea la aportación de la mujer a las artes figurativas, es un hecho que no se han producido reflexiones femeninas destacadas sobre la creación artística: no existe, en forma diferenciada, una crítica o una teoría femenina de las artes plásticas.

El campo más propicio para la producción o para la reflexión de la mujer parece ser el de la literatura, donde hay más obras escritas por mujeres, y desde hace unos años hay un destacado movimiento teórico, la «crítica feminista», que no se limita a comentar, valorar o comprender la literatura femenina, sino también la masculina desde la perspectiva de las mujeres; también en algunos casos algunos hombres han hecho "crítica feminista", adoptando una visión femenina, o pretendidamente femenina.

En principio, la crítica femenina se ha iniciado en forma conflictiva respecto a las interpretaciones tradicionales y se ha centrado en lo que con frase muy al día se puede denominar «el hecho diferencial», es decir, como una investigación basada en el presupuesto de que existe una sensibilidad específica de la mujer en la creación y en la lectura literarias y también en la especulación teórica sobre las obras literarias.

Estos son los hechos, tal como están hasta el momento, y es extraño que únicamente respecto a la creación literaria se ofrezcan reflexiones «femeninas», mientras que no se ha hablado de una teorización femenina sobre las otras artes, aunque haya algunas mujeres críticas del arte pictórico y teóricas o historiadoras del arte. Vamos a formular algunas reflexiones sobre estos hechos y sus causas, y vamos a sugerir algunas explicaciones apoyándonos en su análisis. 


\section{HISTORIA DE LA LITERATURA Y LA CRÍTICA FEMINISTAS}

¿Se puede hablar de una literatura y de una poética escrita por mujeres que sea diferente de la literatura y de la poética escrita por los hombres? Es decir, ¿la creación literaria y la reflexión femenina sobre ella tienen algún rasgo específico que la diferencien de la creación y la crítica literarias masculinas? ¿Hay razón para hablar, como se hace hoy, de una literatura y una poética femeninas?

No es fácil decidirse por un sí o un no, pues la mayor parte de las razones que se han dado y se han repetido incansablemente hasta convertirse en tópicos, son muy discutibles. Sería impensable hablar, por ejemplo, de una investigación física, o histórica, masculina o femenina, y lo más normal sería hablar de hombres o mujeres dedicados a la física o a la historia, sin embargo se ha planteado la posibilidad de que exista una literatura femenina con rasgos específicos y hay en el panorama actual de las tendencias teóricas una llamada «crítica literaria femenina», que aporta un ángulo de reflexión con una visión del mundo y un esquema de valores pretendidamente diferente del que tienen las poéticas «masculinas», pero las razones y argumentos concretos que se esgrimen para mantener esta postura o rechazarla son muy discutibles.

Para afrontar el problema vamos a partir de su planteamiento y de su desarrollo histórico y vamos a situarlo donde se ha iniciado, es decir, en el conjunto de las reivindicaciones femeninas, principalmente donde se cuestionan con más fuerza, en los Estados Unidos de Norteamérica, pues es precisamente en los departamentos de literatura de sus Universidades donde empezaron a surgir los grupos de «crítica literaria femenina» hoy presentes en la mayor parte de los centros.

En Norteamérica los movimientos feministas y de liberación de la mujer se incorporan a la crítica social en temas comunes a hombres y mujeres: en contra de la esclavitud, a favor de los derechos civiles de todos los ciudadanos, en contra de la guerra, etc. Son temas políticos en torno a la actuación del poder y la organización social, donde son bienvenidas las actividades feministas, como las de cualquier otro grupo social, del carácter que sea; pero al plantear el tema de los derechos de la mujer, muchos de los hombres que hacen frente común con ellas en esos otros asuntos, toman una actitud muy diferente que suele oscilar desde la sonrisa comprensiva hasta la mofa y el sarcasmo; la 
razón se sustituye por el tópico, por la broma o la descalificación, de modo que las feministas han llegado a comprender que sus reivindicaciones deben hacerlas frente a los hombres, frente a situaciones o sentimientos de prepotencia de algunos hombres, pues no se trata de alcanzar nada en la teoría, sino en la proyección pragmática de repartir trabajo, responsabilidades y poderes.

Las estadísticas sobre porcentajes de trabajo, sobre sueldos, sobre oportunidades de acceder a puestos de responsabilidad, tanto profesionales como de poder social o político, etc., son sangrantes y hacen casi innecesarios los razonamientos que van abriendo caminos teóricos a la evidencia en el conjunto de la sociedad; sin embargo, sólo de un modo lento se alcanzan cambios en la práctica.

Dejando aparte los datos generales de las estadísticas, que se dirigen de un modo inmediato a la razón y a la organización social, otro de los caminos para poner el dedo en la llaga o para divulgar situaciones no ya injustas, sino absurdas, es el de revestir de ficcionalidad mediante un discurso literario algunas situaciones que, si se reflejan en las estadísticas, no alcanzan tanta eficacia sobre el sentimiento como presentadas con la fuerza de una anécdota vivida o sentida: el convencimiento puede ser más inmediato por la vivencia que por la mente.

Surge así una literatura de denuncia y paradoja que no se limita a exponer casos más o menos injustos en su desarrollo, sino que rechaza el mismo marco de valores y de referencias en que se sitúan y que había servido para dar sentido a historias noveladas o dramatizadas por hombres, aunque presentasen a la mujer desde un ángulo de simpatía o comprensión. En la literatura masculina, la mujer podía ser presentada como una víctima, podía suscitar la simpatía del lector, podía mostrar que había situaciones manifiestas de injusticia, de desconsideración, de descalificación total, etc., pero el marco social de las relaciones hombre-mujer seguía siendo el mismo, y parecía inamovible, de modo que si había un redentor era siempre un hombre, y si había un desenlace favorable y optimista, era invariablemente una boda ventajosa. La mujer, en los mejores casos, no dejaba de ser actancialmente en el relato el objeto de la búsqueda, la finalidad en la historia del hombre, y esto incluso cuando el narrador era femenino, o el relato se hacía tomando a la mujer como foco y como protagonista. Podríamos decir que en el mejor de los casos se llegaba a comprender las transgresiones que la mujer hacía sobre la norma, pero no se advertía que esa norma era «masculina», y que podía y debía ser cambiada porque era injusta. 
No obstante, lo mismo que ocurre con los hombres que reivindican junto a las mujeres algunas cuestiones y se sitúan en contra cuando se habla de los derechos de la mujer, ocurre con los colectivos feministas, que respecto a la literatura y a su valor no se ponen de acuerdo: algunas consideran que la creación literaria no es el campo adecuado para la reivindicación femenina porque es frívolo, y no merece la pena utilizarlo porque es ineficaz, y prefieren olvidarse de la literatura como campo o instrumento de reivincidaciones y orientar su lucha hacia un ámbito exclusivamente político y social.

A pesar del rechazo general o del rechazo de algunos grupos feministas, y a pesar de las dificultades que de ello se derivan, algunas mujeres siguen escribiendo y siguen haciendo reflexiones sobre el arte poético de forma paralela o de forma autónoma respecto al feminismo social y político militante y es frecuente que los esquemas que siguen y los presupuestos en que se apoyan mantengan entre sí algún tipo de relación y sirvan de explicaciones recíprocas.

Según se entiendan las relaciones de poder y de convivencia entre los sexos y según los límites señalados para las reivindicaciones feministas, se originan determinadas mediaciones, expresadas o tácitas, en el texto literario. En este sentido podemos distinguir tres actitudes generales, a las que son reducibles la mayor parte de las variantes históricas que se han dado hasta ahora:

1) Se niega la dicotomía metafísica de masculino/femenino y se considera inútil buscar rasgos diferenciales en la actuación del hombre y de la mujer, y por consiguiente, entre el arte femenino y el arte masculino. Las diferencias que de hecho hay en el número o en las formas y temas de la literatura hecha por mujeres, son de tipo histórico, proceden de la educación diferenciada o se deben a las circunstancias en que se ha desenvuelto la mujer en la familia y en una sociedad organizada por los hombres.

2) Se admite la diferencia masculino/femenino, pero se reclama igualdad de oportunidades de modo que las posibilidades de actuar, y por tanto de escribir, sean las mismas para el hombre y para la mujer. Las formas históricas diferentes deben ser superadas, porque son injustas o absurdas; proceden de una tradicional discriminación del sexo femenino y tienen como origen una visión masculina que, por muy arraigada que esté en la sociedad, es originalmente injusta.

3) Se admite la diferencia masculino/femenino, y se reclama esa diferencia rechazando el orden masculino y propugnando una actua- 
ción propia de las mujeres. Así como la posición anterior buscaba la integración de la mujer en un orden social conjunto masculino y femenino, ésta pretende dar vuelta a una situación que se considera injusta, y reclama no sólo una nivelación de derechos, sino la imposición de un orden femenino, como venganza y resarcimiento de las injusticias históricas.

Desde este marco general que, trasladado al ámbito del arte literario propugna una literatura única no diferenciada, o bien una literatura masculina y otra femenina, en armonía o enfrentadas, se desenvuelve una poética que trata de buscar, o de negar, principalmente en la novela, los rasgos específicos de una literatura femenina.

\section{LA CRÍTICA LITERARIA FEMENINA}

La mayor parte de las historias de la teoría literaria parecen estar de acuerdo en que la poética femenina se puso en marcha con cinco obras: Una habitación propia, de V. Woolf, 1927; El segundo sexo, de Simone de Beauvoir, 1949; The Troublesome Helpmate, de Katharine M. Rogers (1966); Thinking About Women, de Mary Ellmann, 1968; y Sexual Politics, de Kate Millett, 1969. Estas obras, aunque constituyen la base de la crítica feminista angloamericana, no parecen constituir un factor importante en el conjunto de la lucha feminista. El dilema para muchas, a causa de lo que ya hemos expuesto, es separar lo que puede ser un talante artístico y académico de una actitud social y políticamente militante. La mayor parte de las críticas literarias feministas trabajan hoy en el campo académico, a pesar de que se inserten en el marco general o acojan ecos de la lucha feminista que reivindica igualdad de derechos y de actuación ante el poder y para la conducta.

Destacamos como más relevantes para la crítica literaria, dos de las obras citadas, la de M. Ellmann, Thinking about Woman, por su estilo, y la de Kate Miller, Sexual Politics, por su contenido. La primera es una obra maestra de la ironía, como actitud ante hechos que analizados racionalmente resultan paradójicos y absurdos. Irónicamente, puesto que el razonamiento falla, Elmann pone de relieve la injusticia de algunas normas que rigen la conducta femenina y dedica el capítulo final a estudiar las estrategias que emplean las escritoras para enfrentarse airosamente a una situación de machismo: las novelistas han utilizado los estereotipos de mujeres y de literatura sobre mujeres que 
han puesto en circulación los escritores masculinos, pero tratando de llevarlos al absurdo a fin de mostrar su falsedad intrínseca.

A partir de esta obra, se impuso el tono irónico en obras femeninas y empezó a ser considerada la ironía como un rasgo propio de su poética. Sin embargo, es obvio que no puede mantenerse que la ironía sea un rasgo específico de lo femenino; otra cosa es que en esas circunstancias de rechazo de situaciones manifiestamente injustas que se toman como normales, la ironía sea el recurso de distanciación más eficaz. Creo que el modo de plantear los conflictos y las relaciones de lo masculino y lo femenino exigían una actitud irónica, pues puede destacar más la situación que la presentación neutra y objetivista, independientemente de que el autor de la crítica sea hombre o mujer.

Vamos a comprobar que este caso se repite con otros aspectos y recursos: se califica de «femenino» cualquier actitud o forma que se encuentre en el discurso literario firmado por una mujer, aunque su razón de ser derive de la finalidad que se pretenda, de la historia que se cuente, del valor que tenga en sí mismo, etc., y sea realmente un uso común a hombres y mujeres escritoras.

Quizá porque el ambiente era propicio a los planteamientos que hacía, o quién sabe por qué otras razones, Sexual Politics, de Kate Millett, fue la obra que tuvo mayor impacto social y la que suele considerarse como uno de los puntos de partida de la crítica literaria feminista angloamericana actual.

Lo que más se ha destacado de esta obra en referencia a la teoría literaria es el giro que reclama respecto a la posición seguida por el New Criticism, escuela de teoría literaria dominante en las universidades de los Estados Unidos. El conjunto de los llamados «nuevos críticos», aunque con algunas divergencias en los planteamientos y en su aplicación práctica a los textos, coincidía en tomar como objeto de los análisis literarios «la obra en sí». Es el enfoque que seguían también las escuelas críticas europeas hasta mediado el siglo $\mathrm{xx}$ (las estilísticas, los formalismos, los estructuralismos), pues centraban su objeto en el discurso, y estudiaban los rasgos distintivos, las unidades formales o las relaciones estructurales en los límites del texto literario, pues todo lo demás eran abstracciones o se podía considerar extraliterario.

Millett insiste en la necesidad de trascender el texto y prestar atención a los contextos sociales y culturales para entender la obra literaria en toda su riqueza. A partir de Millett toda la crítica literaria feminista defiende esta idea, que suele considerarse como su principal aporta- 
ción, junto con la defensa que hace del derecho del lector a adoptar su propia perspectiva y a colaborar en una lectura abierta, sin sentirse condicionado por la visión del mundo del autor de la obra.

Pero es díficil admitir que esta posición de la teoría literaria sea específica y original de la "crítica feminista», pues si se sitúa en el panorama general de las poéticas del siglo $\mathrm{XX}$, puede comprobarse que coincide con la evolución epistemológica y metodológica general: desde un primer momento en que, bajo el dominio de los métodos decimonónicos de carácter historicista, la investigación literaria centraba el interés en la figura del autor, se pasa a una segunda etapa que polariza la atención hacia el texto y sus límites formales estrictos, para alcanzar en la actualidad una tercera fase, en la que por presión del método sociológico, del psicocrítico y de la pragmática, la poética amplía sus horizontes y sitúa a la obra literaria en el conjunto de sus relaciones con el entorno social y cultural a través de los sujetos (autor-lector), del proceso semiótico de que forma parte (procesos de expresión, de comunicación y de interpretación literarias) y en relación con los sistemas culturales de la época.

Yser fue el primero en afrontar los problemas pragmáticos que derivaban de los estudios lingüísticos de Austin y Searle (el estudio de los usos del habla y sus circunstancias, frente al estudio del sistema de lengua), y cinco años después, Pratt (1977) intenta fundamentar sistemáticamente una teoría del discurso literario sobre la pragmática de los actos lingüísticos.

La liberación que Millett reclama para transcender los límites formales de la obra y para colocarla, dada su dimensión pragmática, en el centro de un contexto cultural, y a la vez reconocer las competencias del lector en los procesos de creación de sentido literario, coincide con la posición de las teorías actuales que reconocen que ha llegado «la hora del lector» y que existe una interacción continuada de la obra literaria con otros sistemas culturales envolventes. La poética feminista, en este punto, se sitúa en línea con teorías como la estética de la recepción, la pragmática semiótica, la sociología literaria, la psicocrítica, la ciencia empírica de la literatura, etc., que, sin negar las posibilidades de un estudio inmanente de «la obra en sí», superan los límites del texto para considerarlo en sus relaciones externas.

En 1969 no es una actitud «novedosa» y mucho menos específicamente feminista, el solicitar la atención del crítico hacia las circunstancias sociales que en el momento de la creación o de la recepción de la obra literaria mediatizan su sentido y sus formas, porque en 1967 se 
abre el curso en la Universidad alemana de Konstanz con el famoso discurso de H. R. Jauss, Estética de la Recepción, que responde no sólo a una doctrina original del autor, sino a un movimiento generalizado en la teoría literaria y presente en las Universidades, que planteaba problemáticamente el papel de la historia literaria frente a la teoría y el papel del lector en el proceso de comunicación literia, y que tenía antecedentes en la teoría semiótica. Los textos literarios, como todos los escritos, establece un circuito de comunicación segmentado: emisor-obra // obra-receptor, creando las condiciones para una ilimitada distancia espacio temporal y cultural. La distancia origina un abanico de variantes con indeterminaciones, tensiones y discordancias semánticas, de modo que la lectura de los textos literarios es, más que una descodificación, una especie de reelaboración activa de un mensaje que se sitúa en unas coordenadas nuevas en cada lectura (Doležel, 1990: 211). Estas ideas, que están en la base de la crítica actual no pueden ser atribuidas a Millet y a su llamada de atención hacia el lector.

Después de estas primeras obras, y bajo el influjo directo o indirecto de sus postulados, sean o no específicos, se desarrolla una crítica feminista en Europa (principalmente en Francia) y en las principales universidades de Norteamérica que se manifestará en dos direcciones fundamentales: a) la primera, y bajo el título general de «crítica de imágenes de mujer», hace un análisis ideológico de los contenidos de las obras escritas por hombres fundamentalmente y un estudio de los modelos de personajes femeninos en la novela decimonónica que va a repercutir en la creación novelística femenina actual de forma notable; b) la segunda, más diversificada y más amplia, aunque posiblemente menos desarrollada y menos combativa porque se desenvuelve en el campo estrictamente literario, trata de señalar los rasgos específicos, si es que los hay, de lo femenino en el discurso y en la trama de las novelas escritas por mujeres.

Durante la década de los setenta se escriben ensayos sobre la literatura femenina que son más bien tomas de postura, porque realmente no son análisis o reflexiones críticas o literarias. Las mujeres se plantean el problema de adoptar un enfoque adecuado para el estudio de la literatura femenina. En 1975 A. Kolodny propone estudiar la literatura femenina comparándola con la masculina, porque en caso contrario, al estudiarla en forma aislada se carece de contraste, y efectivamente, al comparar las novelas de hombres y de mujeres, puede advertirse que es típico del hombre sentirse atrapado por el trabajo, mientras que es típico de la mujer sentirse atrapada por la casa, lo que en el 
fondo es lo mismo: sentirse atrapado por lo cotidiano, que para el hombre era el trabajo y para la mujer las faenas domésticas.

La novela masculina habla de los hombres, atrapados en el trabajo diario, pero no advierte la misma situación en la mujer, de la que sólo ve los aspectos frívolos y de falta de responsabilidad en el trabajo, como si el de la casa no contase, y ante este hecho, la novela femenina se caracteriza por una «percepción reflexiva» sobre su propia situación en la familia y en el trabajo cuando lo desempeña.

Para destacar las diferencias y descubrir el verdadero ser y estar de la mujer, la novela suele seguir procedimientos de «inversión», como la ironía utilizada por Ellmann, que consiste en poner al revés las imágenes estereotipadas y tradicionales de las figuras novelescas, y tratarlas cómicamente. Es una estrategia subversiva de descripción que suele considerarse típica de la mujer novelista (Gilbert y Gubar, 1979), y que desemboca frecuentemente en un discurso irónico.

De 1979 es el artículo de E. Showalter, «Toward a feminist Poetics» donde la autora distingue una «crítica feminista» y una «ginocrítica». La primera es la lectura feminista de las novelas escritas por hombres, la segunda es la lectura feminista de las noveles femeninas. El método que propugna esta autora es lo que pudiéramos denominar «hermenéutica de la sospecha», que al igual que el movimiento deconstructivista, intenta leer el texto como si el discurso no fuese el medio de expresión, sino de ocultamiento: las contradicciones, los conflictos, las lagunas y los silencios que tiene la novela masculina pueden servir de indicios, según Showalter, para alcanzar el verdadero sentido de la obra, que no coincide con el que abiertamente se cuenta. Las novelas femeninas no necesitan esta lectura porque son espontáneas, directas, reflexivas, y no ocultan, sino que manifiestan lo que quieren como testimonio de las experiencias vividas por las autoras.

La cultura femenina «acallada» durante siglos se descubrirá aplicando criterios históricos, antropológicos, psicológicos y sociológicos a la lectura de los textos literarios. Sin embargo, este tipo de crítica puede llevar a la comprensión del texto y a la explicación de sus contenidos, pero indudablemente no es «crítica literaria», y así lo han entendido otros autores (Moi, 1988: 80-97).

M. Jehlen (1981) propondrá también estudiar las literaturas masculinas y femeninas comparativamente para obtener referencias contrastadas, como había señalado ya Kolodny pocos años antes (Moi, id.) 
En estas autoras encontramos más bien propuestas que realizaciones, más el anuncio de un «deber ser» de la crítica y teoría feministas que directamente el ser de una crítica y una teoría. El análisis ideológico de los personajes femeninos no deja de ser una paráfrasis temática, y la discusión sobre si conviene hacer estudios autónomos o comparados (masculino/femenino) es, en todo caso, un tema metodológico. Estamos en tiempos iniciales de toma de conciencia y búsqueda de caminos y cualquier orientación que apunte la crítica suele originar aplicaciones en la creación literaria femenina. Vamos a comprobar cómo se da esa interacción casi inmediata entre obra literaria y teorías literarias.

\section{a) Crítica de «imágenes de mujer»}

A partir de 1980, en la Universidad americana, y en relación con la obra de Ellmann, proliferan en los Departamentos de Literatura los cursos de crítica femenina que analizan la presencia de la mujer en la literatura, y las imágenes de mujer en los estereotipos diseñados por los hombres. Se denominó «crítica de imágenes de mujer», porque en 1972 se publicó Images of Women in Fiction: Feminist Perspectives, que se reeditó varias veces y que era el trabajo en colaboración de 21 autores (19 mujeres y 2 hombres), todos los cuales coinciden, al estudiar autores y autoras de novelas del siglo XIX, en la falsedad de los personajes femeninos que pululan por los mundos ficcionales de la novela.

A pesar de la denominación de «imagénes de la mujer», este tipo de crítica no es exclusivamente temática, pues trata también temas pragmáticos y sintácticos, por ejemplo, se interesa mucho por la función- del lector en el proceso de la comunicación literaria, a partir de un concepto pragmático del texto literario, como había sugerido K. Millett.

En general la crítica de «imágenes de mujer» acepta como uno de sus presupuestos el de la polivalencia semántica del texto literario y, por tanto, la ineludible colaboración dinámica del lector en el proceso de comunicación literaria, la «reelaboración activa» del lector, ante la posibilidad de varias lecturas. Jauss, apoyado en el concepto filosófico de «horizonte de conocimiento» de Heidegger, habla de la posibilidad de que una obra tenga diversos sentidos a lo largo del tiempo - lo que 
justificaría una historia de la literatura, que sería una historia de las interpretaciones diacrónicas de la obra-, ya que puede entenderse que una lectura, es decir, una interpretación es el resultado de la fusión del «horizonte de expectativas» del autor, que codifica la obra, y del «horizonte de expectativas» del lector, que la interpreta. Cada lector tiene un modo de leer y de captar el discurso literario y el mundo ficcional de la novela, puesto que está condicionado por una determinada competencia de lectura personal e intransferible. La historia de la literatura sería la historia de la fusión sucesiva de horizontes de lectura con el horizonte de creación de las obras literarias.

En relación directa con estas posibilidades hay que admitir que la obra literaria, abierta a la interpretación, podría ser leída de diferente forma por las mujeres o por los hombres, si es que efectivamente hay diferencias en la competencia lectora de hombres y mujeres.

La pretensión de universalidad de una lectura determinada (que suele ser la del crítico que mantiene tal idea), no es más que un intento de transducción, es decir, un intento de imponer una lectura como única, o como «verdadera», basándose en el presupuesto de que la obra literaria tiene un significado unívoco, el que ha querido darle el autor y al que el crítico tiene acceso, por un especial privilegio, o por su especial competencia. La interpretación de que tal o cual imagen de mujer es «verdadera» o falsa, es un juicio totalmente subjetivo, puesto que no existe una posible verificación o falsación con un prototipo o con un modelo de persona que tenga estabilidad o aceptación social objetiva alguna. Mukaroovski, desde una posición semántica próxima a la de G. Frege, niega todo valor de «verdad» a los textos literarios, en los que prevalece la función poética y la cuestión de la verosimilitud no tiene sentido alguno. La «verdad» del lenguaje literario es un problema de semántica interna, no de contraste referencial, puesto que los llamados hechos reales, es decir, los hechos narrados que se basan en hechos efectivamente sucedidos y los hechos ficcionales, inventados por el autor, se integran en la unidad de la función poética y pueden ser interpretados en el conjunto de la obra sin necesidad de buscar la referencia real. Es decir, que por el hecho de integrarse en la obra literaria los hechos reales se incorporan a un mundo nuevo, el ficcional.

Cualquier lectura supone una transformación de la obra literaria, puesto que nunca se lee la obra completa, que por ser artística está abierta a diversos sentidos. Las figuras de los personajes femeninos pueden «leerse» desde ángulos de visión muy distantes y, desde luego, desde un horizonte de expectativas o de conocimiento muy diferente 
del que sirvió del marco al autor de la obra, y sin duda pueden ser interpretados de forma diferente por hombres y por mujeres. Desde esta perspectiva la «lectura verdadera» queda trascendida, si no anula$\mathrm{da}, \mathrm{o}$ en todo caso, puede ser una más entre las posibles.

La polivalencia del texto literario puede apoyar la explicación genética de una poética femenina; la estética de la recepción, en su reconocimiento del papel activo del lector, la apoyaría también al considerar que el lector no es un mero receptor pasivo, sino que tiene una función directa en la creación del sentido literario; y asimismo la deconstrucción podría corroborar la misma idea y servir de marco de referencias teórico en su negación de una interpretación central y única; las interpretaciones marginales, el mismo hecho de la diversidad de interpretaciones, la diseminación del texto, etc., pueden justificar en algún sentido «lecturas feministas», entre otras lecturas marginales o centrales.

Podríamos admitir que el principio más general de la crítica feminista, que coincide con una actitud deconstructiva, es precisamente que ninguna poética puede ser objetiva y ninguna puede presentarse como verdadera o como única y, por tanto, puede haber un modo de lectura masculino y un modo de lectura femenino, independiente de que cada lector pueda individualizarse en su interpretación a partir de su propio horizonte de expectativas.

También desde una perspectiva semiótica este principio resulta fundamental y se hace más extenso: considerando la obra literaria como elemento intersubjetivo en un proceso de interacción semiótica con tres elementos básicos: el autor, la obra y el lector, el relativismo semántico y la apertura interpretativa del texto no procede solamente de la actividad del lector, sino también de la ambigüedad buscada por el autor y plasmada en las relaciones pragmáticas que pueda establecer la obra como proceso semiótico autónomo.

Los límites de sentido no se agotan en los límites formales de la obra; las intenciones del autor pueden ser tan amplias como se quiera, pero en todo caso son determinables sólo parcialmente a través de la obra y a partir de los estudios históricos y biográficos y, por último, la creación de sentido por parte de los lectores no puede considerarse agotado nunca. En un proceso semiósico de esta naturaleza, en el que el creador de la obra actúa con intenciones que son prácticamente inasequibles al crítico, con un objeto, la obra literaria, de texto polivalente y discurso ambiguo, y con un lector que participa desde ángulos históricos, sociales y personales diversos, no cabe duda de que ninguna crítica puede ser total, objetiva y neutral, porque en ningún caso están 
agotados ni claros los límites de los elementos relacionados en la explicación y en la comprensión literarias, y cada lector o crítico podrá poner en juego sólo una parte de los indicios y de los datos del texto, los que su competencia le permita considerar.

Estos argumentos desembocan necesariamente en un relativismo crítico que es necesario advertir como punto de partida. Claro que hay interpretaciones que el texto rechaza y hay lecturas coincidentes en buena parte. El relativismo es más teórico que práctico en la realidad, pero en cualquier caso no se puede negar y conviene tenerlo en cuenta a la hora de calificar de «verdaderas» o «falsas» determinadas lecturas, y de «completas» o «parciales» otras. Estos adjetivos hay que mirarlos con precaución en cualquier tipo de crítica, masculina o femenina. El análisis crítico puede poner énfasis en el autor (proceso de producción), en la obra (producto objetivado), o en la recepción (proceso de interpretación), o en el conjunto, pero en cualquier caso será parcial y será relativo, aunque se refiera al conjunto. Los criterios de valoración masculinos y femeninos puede ser diferentes, porque pueden encontrar apoyos diferentes en la obra.

La interpretación de las «imágenes de mujer», como la interpretación de cualquier otro elemento o unidad de la obra literaria, está justificado teóricamente por la capacidad inagotable sémicamente del discurso literario y por la competencia, siempre diversa, de los lectores; en la práctica histórica tiene un desarrollo concreto y da lugar a unas posibilidades también concretas que derivan de las formas en que se ha enunciado.

Images of Women in Fiction mantiene que las figuras de mujer que presentan las novelas escritas por hombres son «falsas», porque no responden a la realidad. Las causas son de muy diversa índole, unas propias del texto literario, otras debidas a la visión masculina de la mujer. Quizá sería más acertado decir que son imágenes que no gustan a las lectoras, porque decir que son «falsas» es una mistificación del lenguaje referencial con el lenguaje literario.

Los autores no alcanzan nunca el límite (no pueden hacerlo) de lo que puede decirse de una mujer, por tanto se ven obligados a seleccionar algunos aspectos de la figura, de la vida, de las relaciones de sus personajes femeninos, que quedan necesariamente deformados al perder el equilibrio que les da la realidad; el discruso literario se construye, en este sentido con muchos blancos. Del mismo modo que una fotografía congela el movimiento, el discurso literario, por su propia naturaleza, selecciona algunos aspectos de lo que describe y expone 
linealmente en sucesividad lo que es un conjunto simultáneo. Los autores presentan por medio del narrador del relato unas imágenes de mujer que necesariamente son construcciones logocéntricas, figuras verbales realizadas desde su competencia emocional, mental, discursiva, etc., y desde su visión particular.

Pero esto ocurre al diseñar la figura literaria de las mujeres y también al diseñar la figura literaria de los hombres, y les ocurre a escritores y a escritoras, en la descripción y en el relato; y además pasaría lo mismo al considerar cualquiera de las unidades sintácticas: el relato no puede dar cuenta de todos los aspectos de las acciones, porque las conexiones serían inacabables, no puede dar testimonio del tiempo de todos los personajes, ni siquiera de todo el tiempo de un personaje y se ve obligado a seleccionar algunos segmentos de su trayectoria vital, y tampoco puede describir todos los espacios en los que están o por los que se mueven, pues sería eterno el empeño. No se puede apoyar una poética femenina en aspectos que son comunes, o en bases que no son ciertas.

La teoría de que la literatura es reflejo directo de la realidad es muy discutible, y la teoría del personaje como trasunto de la persona real no se mantiene, entre otras cosas, porque si no se puede acceder a un concepto fiable de «persona real», como prototipo, ni siquiera como individuo, y si el conocimiento del interior de la persona resulta muy dudoso, mal puede tomarse como modelo literario y mal pueden contraponerse imágenes literarias y entidades reales no precisas.

Lo que sí puede advertirse es que, según épocas y autores, el cañamazo social en que se sitúan las figuras de los personajes de la novela, y la actitud que sirve de mundo referencial al autor y al texto, están mediatizados por ideologías que ven como «normales» situaciones de opresión y de injusticia, con las que parecen identificarse el narrador o los autores, pues no las rechazan; carecen de la distancia ética necesaria para mostrar irónicamente lo absurdo de tal situación o para rechazar conductas que desde otra perspectiva puedan ser poco lógicas, sencillamente porque en su imagen del mundo son normales. Esta actitud es la que puede diferenciar una novela masculina de una femenina, o una imagen de mujer dada por un hombre o por una escritora: lo que el novelista puede presentar como normal, irrita la sensibilidad de las lectoras porque son más sensibles a la injusticia del tratamiento que la mujer recibe en este mundo ficcional.

Es muy distinto exigir al novelista testimonios «verdaderos» $\mathrm{e}$ interpretar la novela como un testimonio directo de la realidad, a advertir 
que sus historias se construyen sobre una anécdota, unos principios o un sistema ético, con los que no se está de acuerdo, porque son injustos. No se trataría tanto de rechazar el valor testimonial de la novela y sus valores miméticos directos al presentar situaciones injustas que se pueden dar o no en la forma en que se ofrecen en el mundo empírico, como de criticar el código ético y el mundo referencial que les da sentido en los límites de la obra. Lo discutible sería la mimesis homológica de las estructuras jurídicas, sociales, familiares, individuales, etc., que no sería adecuada.

Las novelas, según la crítica de «imágenes de mujer», presentan personajes femeninos cuyo modo de ser y de actuar responde a condicionamientos sociales, a circunstancias familiares y a educación personal, en total coherencia, aunque en sí mismos sean injustos y los desenlaces de las situaciones responden a unos códigos éticos que se identifican con los tradicionales de una sociedad machista, admitidos en forma dogmática; la mayor parte de las mujeres muy discretas de nuestro teatro clásico mienten con absoluta soltura, son hipócritas, no tienen el menor respeto o cariño a sus padres y hermanos, porque son personajes despojados de toda libertad, es decir, son puramente actantes de una función: sujetos parà el engaño, objetos para la conquista, ayudantes, oponentes, etc.; y, más que personajes complejos en sus diversas facetas, con unas circunstancias familiares determinadas, son actantes literarios unilaterales que no tienen más responsabilidad que la que se deriva para su funcionalidad; jamás actúan como sujetos libres, capaces de elegir, y sólo con engaño pueden desempeñar su función literaria. El valor de la libertad se considera en el teatro de «capa y espada» como un valor primordial que justifica, puesto que no las hace malvadas, sino cómicas, a las mujeres que mienten, engañan, simulan, etc., para poder elegir de algún modo. Si estas mujeres son inversión de la realidad, o si su comportamiento en referencia a la realidad social de la época resulta absurdo, no interesa en el ámbito literario donde alcanzan su «verdad» al identificarse con la función que les da la trama de la obra y sus secuencias y funciones.

Es posible que esas imágenes de mujer del teatro español o de la novela decimonónica de adulterio se sigan con simpatía, que el narrador las presente disculpándolas y que el lector pueda llegar a ver la paradoja personal y social en que se mueven, pero las lectoras se molestan ante el código ético que sigue la sociedad, porque sus principios son absurdos. Las lectoras, sin duda, serán más sensibles a la remoción de los principios que dan coherencia a esas imágenes de mujer, y no es infrecuente encontrarse con lectoras que rechazan de un modo frontal 
figuras como Madame Bovary, Ana Ozores, Fortunata, etc., que suelen resultar muy entrañables y hasta disculpables para los generosos lectores masculinos, que se sienten magnánimos ante sus faltas y pecados, porque son víctimas del sistema ético cuyas normas transgreden, pero que ellos mismos han puesto y les parece indiscutible. Las lectoras no pretenden compasión, sino que cambie el sistema; no sólo que se disculpen sus transgresiones, porque éstas no lo serían con otro sistema ético más justo y más lógico que tratase por igual a los hombres y a las mujeres. La «verdad» de esas imágenes de mujer es una cuestión compleja y no está en relación directa con la realidad social, sino más bien con el marco que les da coherencia estética: se presentan como personajes cómicos o como víctimas compadecidas de un esquema ético cuya injusticia manifiesta o cuyo absurdo no se discute.

Lo que se advierte en las imágenes de mujer creadas por hombres, y hasta por mujeres, en las novelas decimonónicas (la Nucha, de Los Pazos de Ulloa, o la Sabel de la misma novela de Pardo Bazán, pueden incluirse), es que están generalmente en situaciones de injusticia social, de opresión familiar, de falta de oportunidades de trabajo y de cultura, que no es el mismo en que están los hombres y esto se expone como un hecho que refleja un sistema de vida y de organización de la convivencia, es decir, representan en el mundo ficcional de la novela situaciones que se dan en la realidad, sin contraste alguno con otras situaciones como deben ser y la reacción y conducta de las mujeres son de total sumisión, de seguimiento, de falta de rebeldía, etc., y esto irrita a las lectoras.

Las «imágenes de mujer» propuestas en la novela son víctimas compadecidas, que se ven con simpatía por los hombres, pero que no responden a la idea de las mujeres que reaccionan contras esas situaciones como lo harían hoy las mujeres desde su horizonte de conocimiento o sus expectativas éticas y estéticas. Son mujeres que en todo caso se presentan como víctimas de una situación concreta, pero que no reclaman un cambio del sistema. Quizá en la lógica interna de las obras, y debido a los tiempos, no podría plantearse esa reacción, que hoy parece lógica a las mujeres del siglo.

Podemos advertir que estamos ante una crítica de contenidos hecha desde una perspectiva deontológica de la literatura que quiere exigir a la novela una función de denuncia, con la finalidad de mejorar las condiciones de vida de las mujeres en la realidad social. Lo que ocurre es que se plantea en términos de «verdad», que quizá no sean los más pertinentes para el texto literario. 
En este sentido, la «imagen de mujer» que dan los novelistas decimonónicos es una imagen falsa, alejada de la realidad que quieren las mujeres, sobre todo en la actualidad, pero además es una imagen poco atractiva para las lectoras, que se enervan con figuras sumisas al hombre, poco avisadas en sus pensamientos y poco prudentes en las pocas posibilidades que tienen de elegir, etc. Suele darse el caso curioso de que la mayor parte de las novelas realistas decimonónicas, escritas por hombres, se estructuran sobre una protagonista femenina, a la que no suelen dejar la palabra, aunque sitúen en ella el foco de la narración, es decir, son relatos con un narrador masculino y con una visión convencionalmente femenina, que no suele ser muy acertada, según dice la mayoría de los críticos femeninos y masculinos actuales.

El tema está abierto a estudios detallados y a interpretaciones desde perspectivas muy diversas sobre la función del lector, sobre la función y el ser de la literatura, sobre su valor de testimonio, de estímulo, de juego, sobre su valor cognitivo, emotivo, etc. Sobre todo, el tema está abierto a discusión porque las imágenes de hombre que presenta la novela, o el teatro, también son poco verosímiles, poco reales, nada convincentes. Y, por último, porque ocurre que en las novelas escritas por mujeres, las imágenes de hombre que crean no parecen ser muy del gusto de los hombres. El contraste entre la idea que la mujer tiene sobre la mujer no coincide con la que el hombre tiene, y la imagen que el hombre tiene sobre el hombre no coincide tampoco con la que tienen las mujeres. A partir de la disconformidad de la crítica feminista de «imágenes de mujer» se pueden plantear las posibilidades y límites de la obra literaria para la creación de mundos ficcionales que copien isomórficamente u homológicamente el mundo empírico.

\section{*****}

Porque se da la paradoja de que las novelistas actuales andan a la búsqueda de «imágenes de mujer» que puedan ser más «reales», o digamos más acordes con la visión femenina, y tampoco parecen alcanzar la venia general, no ya de la crítica masculina, sino de las mujeres lectoras o críticas.

Vamos a analizar algunas novelas de una escritora española actual, en las que los personajes femeninos ofrecen la oportunidad de contrastar diversos tópicos formulados a propósito de la narrativa femenina y de la crítica de «imágenes de mujer». 
En 1993 publica Marta Portal Pago de traición, relato en el que una mujer cree que podrá llegar a conocer hasta el fondo su propio ser, porque está dispuesta a analizarse desde su Yo, que «sabe más que su conciencia». El Yo, que puede desdoblarse en sujeto de la historia y en narrador, puede autoanalizarse, puede buscar datos para tomar juicios, puede colocar al mismo nivel de la conciencia otras capacidades de su espíritu: el discurso lógico, los instintos, la intuición, la memoria, etc., e indagar sobre una historia para comprenderla en su totalidad y para explicarla en sus causas.

La conciencia de la narradora-protagonista acepta un sistema de valores, que le sirve de canon para justificar su conducta, más allá de la propia estimación, o del propio acuerdo con su conducta. El Yo de la narradora puede ser depositario del mismo código ético que contrasta con la lógica de la historia y que puede objetivar en otras historias y respecto a otros sujetos, pero puede también distanciarse de ese código y proponer otro, teórico o llevado a la práctica.

La protagonista-narradora de Pago de traición intenta ir más allá de su propia conciencia y vive su vida en un continuo fluir entre decisiones, enfados, remordimientos y su instinto acuciante: sus días transcurren sin que en ningún momento se detenga a reflexionar sobre el bien y el mal, sobre los límites éticos de su modo de actuar, sobre la validez social de su propio código, y vive sus circunstancias sobre un ambiente social del que no parece discrepar. No encuentra contradicción alguna en la infidelidad al marido, porque en su corazón hay espacio para el marido y para el amante, sin que se enfrenten afectivamente, sin plantear problemas de exclusión.

Esta es la situación en la primera parte del relato: desde el punto de vista de la mujer ese código de conducta no parece ofrecer dificultades éticas; en todo caso el problema se va a plantear al contrastar su validez social, familiar, o para otras personas.

La narradora, que no tiene nombre (la autora dice que no le hizo falta nombrarla, lo que es indicio de su valor prototípico como «imagen de mujer» diseñada por mujer), adopta una competencia épica, pues cuenta historias: la suya y la de su madre; tiene también una competencia dramática, pues dialoga en un presente progresivo, sobre todo en la segunda parte de la novela, con un personaje, don Ángel, que le va creando conflictos dramáticos vivenciales; y desarrolla una competencia reflexiva y valorativa al recorrer el panorama de su compleja situación y contrastarla con la vivida por su madre, aunque esto no lo haga directamente en un paralelismo textual, sino que se deduz- 
ca de la lectura de la primera y la segunda parte de la novela. La «imagen de mujer» que resulta no parece convencerla, no parece que pueda aceptarla como modelo. En este sentido parece tener razón A. Pratt cuando advierte que el punto de vista de las novelas de concienciación femenina tienen, por lo general, un desenlace desilusionante, pues al reflexionar se descubren los límites. El mundo de la ficción parece muy poco optimista en la búsqueda de la identidad femenina. Ante una situación idéntica, la imagen propia y la imagen de la madre no son tratadas de la misma manera y se plantea un conflicto de límites, que la novela de $\mathrm{M}$. Portal no resuelve, porque le basta con plantearlo. El adulterio, vivido como tragedia y situación familiar y social conflictiva en la novela decimonónica, es vivido como «cotidiano» por la protagonista de Pago de traición, y sin embargo esta misma mujer se desconcierta ante el adulterio de su madre.

El desenlace no es muy optimista para la narradora: la indagación por su vida y el buceo por el pasado de su madre la lleva a una gran confusión hasta el punto de renunciar a un conocimiento; la euforia primera con que afronta la objetivación de su historia («yo sé más que mi conciencia»), se reduce bastante cuando llega a Madrid, de vuelta del periplo por su infierno particular en busca de sí misma; parece que la rutina volverá a imponerse y está abocada a caer en la vida diaria que desgranará el afán de cada día, sin horizontes más amplios: un cómodo dejarse llevar, una actitud de recibir lo que la vida traiga para bien o para mal, será la única forma de vida que espera a una mujer que bordeó, con sus intentos el conocimiento de la verdad y el diseño de una imagen de mujer válida en generaciones sucesivas. Como en el caso de Edipo, el generoso empeño en el conocimiento es típico del género humano, pero el contenido del conocimiento defrauda siempre y lleva a la tragedia más intensa o al conformismo de una vida diaria, agotada en su propia inmediatez. La mujer, como el hombre, quiere saber y se dispone a hacer lo necesario para alcanzar el conocimiento, pero descubre que lo que ha hecho no está de acuerdo con el código vigente y se castiga a sí mismo; o descubre que el código que realizaba en su vida no vale para el género humano, y se tapa los ojos. El lector deduce en uno y otro caso que es necesario un sistema de valores con unos límites: se puede matar en legítima defensa, pero no al padre; se puede ser adúltero, pero no puede serlo la madre, ya que la infidelidad no produce conflictos ni en el sujeto infiel, ni en el marido (no está probado en el texto, pues omite el punto de vista del marido), pero resulta muy doloroso para los hijos, que pierden su seguridad y hace que su mundo se venga abajo. 
Las más destacadas heroínas decimonónicas se enfrentaron al adulterio como situación límite y la novela ofreció un muestrario amplio de las consecuencias que pueden derivarse de su conducta: la pérdida del marido y del estatus social, incluida la propia estima (La Regenta); la sumisión total a la criada para evitar el escándalo y conservar al marido (El primo Basilio); la desesperación por la pérdida del hijo hasta llegar al suicidio (Ana Karenina); la sordidez de las deudas y de la mentira continuada y la renuncia al mundo de fantasía creado por las ficciones literarias (Madame Bobary), etc. La mujer adúltera que era víctima de una circunstancia a la que se inmolaba en grados diversos por la fuerza de su pasión es compadecida por los lectores y es rechazada por la crítica de «imágenes de mujer» que considera a esas heroínas faltas de carácter, poco luchadoras, con escasa iniciativa frente a las exigencias sociales.

La novela actual presenta mujeres «liberadas» en las que el adulterio no adquiere las dimensiones de desastre que tuvo en la novela del siglo XIX y el texto intenta igualar a la mujer con el hombre e indaga hasta dónde se puede ir por ese camino de liberación. El adulterio es la anécdota, la situación-límite que se toma como ejemplo, porque el tema de la novela es, según una posible lectura, el diferente grado de uso de la libertad que tiene el hombre y la mujer: lo que para uno es tolerable, y hasta bien visto por la sociedad, es para la mujer ocasión de oprobio, de desastre personal, familiar y social. Y si de la novela decimonónica pasamos al teatro de capa y espada, las mujeres mentirosas, hipócritas, sin dudas ni recelos, alcanzan su objetivo suscitando la sonrisa de los hombres y la indignación de las espectadoras.

A partir del rechazo de las figuras femeninas diseñadas por hombres, a partir de un código ético que reclama para la mujer la misma libertad que para el hombre, la protagonista de Pago de traición se presenta con toda naturalidad, como se presentaban los hombres en la literatura de todos los tiempos, viviendo un adulterio; razona que en su mundo afectivo hay sitio para el marido y para el amante, por tanto, si no se sale de su ámbito personal o familiar (aunque, insisto en que no se manifiesta el punto de vista del marido engañado), no parece haber ningún conflicto, ni daño para nadie, pero el relato, expresado en un monólogo interior no dirigido de la protagonista, no muestra el mundo exterior: nada sabemos del marido, si sufre o no con la infidelidad de la mujer; nada sabemos de la forma en que la madre vivirá el adulterio de su hija, porque nada sabemos de ella hasta más tarde, y no podemos contrastar su reacción ante sus propios amores adulterinos y los de su hija; el relato nos presenta exclusivamente la visión de 
la protagonista-narradora y nada más: ella no sólo está en el centro de todas las relaciones, sino que no dice nada de los otros extremos. $Y$ está claro que en su interior el adulterio no provoca conflictos, y también parece claro que cree que no los provoca en los demás.

Viene un tiempo de desastres, y la muerte de los que quiere la hace reflexionar sobre sí misma, su conducta, su modelo de mujer: muere el marido, muere la madre, el amante le anuncia que va a casarse con otra. Todo es circunstancial, no hay relaciones de causalidad entre estos hechos, porque en la vida pueden presentarse así. También por cincunstancias fortuitas, la mujer quiere conocer la historia de su madre: se siente responsable de su muerte porque la ha rechazado cuando le pedía ayuda, y también porque después de su muerte ha encontrado un medallón con una vieja fotografía de un hombre joven; intrigada por la foto, hace un viaje al pueblo de su infancia y allí, por las confidencias inducidas de don Ángel, un sacerdote amigo de la familia, conoce la historia; su madre cometió adulterio y estuvo a punto de abandonar a la familia para marcharse con su amante, pero se detuvo por la enfermedad del marido y por la posibilidad de que los hijos quedasen solos. La decepción de la narradora al conocer que su madre había sido infiel a su padre y al pensar que estuvo a punto de ser abandonada por ella, es terrible y la mujer que con tanta facilidad vivía sus relaciones adúlteras, soporta con dificultad las de su madre, tan alejadas en el tiempo. La imagen de mujer, contrastada en este tema tradicional en la novela, la liberación de la mujer, parece estar limitada con la figura de la madre y parece que los hijos rechazan el adulterio de la madre, la falta de fidelidad al padre. Es una «imagen de mujer» la que aquí se perfila con una personalidad ambigua, poco definida como prototipo, aunque de una gran profundidad y riqueza literarias. ¿La novela anda a la búsqueda de «imágenes de mujer» coherentes, verosímiles, verdaderas, reales, o bien busca figuras literarias válidas, ambiguas, problemáticas?

El tema es recurrente en la trayectoria narrativa de Marta Portal, pues su primera novela, $A$ tientas y a ciegas, dibuja una variante de esa imagen de mujer. Sara, la protagonista vive con absoluta facilidad su adulterio y ante la naturalidad con que se lo cuenta a sí misma, pues se expresa en monólogo interior dirigido a su amante, comenté con la autora el contraste con la figura de Ana Ozores, que resiste el asedio de don Álvaro Mesía 28 largos capítulos en los que el narrador busca toda clase de explicaciones (exigencias de la carne, insatisfacción, soledad, aburrimiento, falta de recuerdos, desprecio hacia una sociedad hipócrita, desamor, asedio, etc.) para justificarla y para hacerla simpá- 
tica al lector, a pesar del adulterio. Marta Portal me dice en una carta de 1983:

«Me ha hecho gracia que encuentres que mis adúlteras son muy "fáciles" comparadas con Ana Ozores. Claro, han pasado cien años y las féminas se han liberado. Además el hombre escritor proyecta en sus protagonistas la imagen que él tiene, o que él quiere, o que él recha$z a$ de la mujer. Y esa proyección tal vez no es la que es. Creo que en la última narrativa escrita por mujeres en España estamos asistiendo al descubrimiento de la mujer por la mujer, sin el influjo de las caracterizaciones masculinas. Lo que quiero decir es que si mis adúlteras son más "fáciles" es que son más sinceras o menos complicadas.

Me da que pensar, porque es sintomático, lo que dices de que en ellas - las protagonistas- la reprobación del adulterio se expresa sólo en función de los hijos o de la madre».

En cien años, desde que se escribió La Regenta hasta que se publica A tientas y a ciegas, o Pago de traición, han cambiado las mujeres, ha cambiado el marco de referencias sociales, ha cambiado el código ético que explica su conducta, y ha cambiado el autor que, siendo hombre, imagina un mundo interior de dudas, de indecisiones, de tormentos, para su protagonista y, siendo mujer, no se los plantea, porque atiende a los hechos y proclama el derecho a esa forma de actuar de la mujer, semejante a la forma de actuar del hombre. Si en La Regenta don Álvaro, o en su nombre el narrador, no justifica su conducta, y sería quizá poco literario hacerlo - no recuerdo ninguna obra en la que el don Juan dude de su conducta e intente justificarla- en $A$ tientas y a ciegas, la protagonista, Sara, no se justifica tampoco, no se cree en la necesidad de hacerlo, si bien con la perspectiva de la maternidad ve las cosas de otro modo y rechaza el adulterio. Si en Pago de traición, la narradora no se para a pensar sobre su infidelidad, sino sobre la de su madre, en $A$ tientas y a ciegas la protagonista no reflexiona sobre su adulterio hasta el momento en que ve la posibilidad de tener hijos legítimos o adulterinos.

La crítica literaria de «imágenes de mujer» habrá cumplido su objetivo al delatar la falsedad de las figuras de mujeres en la novela decimonónica y la visión desde la que se las enfoca y quizá al impulsar a la literatura femenina a la búsqueda de nuevas imágenes de mujer; la novela femenina actual está experimentando sobre los tipos de mujer, en igualdad con los tipos de hombre, pero tiene sus dificultades al establecer los criterios que pongan límites y normas a las conductas. 
No creo que la sinceridad o la sencillez lleven directamente al adulterio, porque esto supondría que todas las mujeres son adúlteras y sólo las sencillas o las sinceras lo confiesan, ni es éste el problema que plantean las novelas, sino el de la libertad y sus límites; la literatura femenina tendrá que sacudirse la imagen de la mujer como sujeto de adulterio, que debe ser castigada con la muerte, con el desprecio social, con la pérdida de los hijos, etc., pero también debe encontrar las razones para los límites de la conducta en razón de los hijos, o por ser la madre (Sara quiere hijos legítimos), porque necesitará buscar un código ético, si es que lo admite, que no establezca unas situaciones de injusticia comparativa y que quizá pueda ser común al género humano: si algo se rechaza en razón de la maternidad, o de la filiación, quizá deba ser rechazado también en razón de la paternidad, pues la procreación es un juego de los dos sexos, y nunca se había seguido en un relato la consecuencia que para los hijos podía tener el adulterio del padre. La novela de Marta Portal tiene una dimensión diacrónica que proyecta el adulterio hacia sus efectos en los hijos, $o$ en las relaciones con la madre, y que sitúa el problema fuera de las relaciones de pareja.

Por otra parte, la novela femenina, y también la masculina, tiene que darse por enterada de que las mujeres, lo mismo que los hombres, pueden tener otros temas, otras conductas que pueden estar alejadas de una sobrevaloración de la sensualidad, de los sentimientos amorosos y de las relaciones entre los dos sexos. La novela de adulterio, es decir, la novela de adulterio femenino, me parece que ha sido suficientemente explotada y habrá que buscar otras historias.

En su última novela, El ángel caído, Marta Portal plantea, sobre una anécdota de estricta actualidad, unos problemas de relaciones y de situaciones, unas imágenes de mujer y un discurso literario, desde perspectivas nuevas y con aspectos nuevos en las conductas de las mujeres y en las de los hombres. Para ello cambia el narrador, que no es una mujer como en las dos novelas citadas anteriormente, sino un hombre, Eugenio Reverter, si bien su discurso subjetivo, en primera persona, alterna, cuando lo requiere el contenido, con la objetividad de un narrador omnisciente en tercera; el tema central ya no es el adulterio - aunque no faltan- y las imágenes de mujer son varias y tienen distinto espesor, pues unas veces están descritas en primera persona, es decir, se presentan al lector a partir de una visión subjetiva del narrador, y otras veces están observadas objetivamente por un narrador omnisciente; y en algún caso se presentan ellas mismas, con su propia voz o su acción directa. No hay pues imágenes de mujer vistas 
desde la perspectiva única del narrador, como en la novela tradicional, o imágenes de mujer creadas por el autoanálisis de una narradora.

La anécdota que sustenta los esquemas de relación entre los personajes está integrada por negocios de multinacionales, por fracasos de matrimonios, por viajes y reuniones, que se desarrollan en los espacios conocidos de Madrid: vivienda en el barrio de Salamanca, despacho en la calle de Alfonso XII, paseos por El Retiro, por la calle de Alcalá arriba y abajo, por viajes al extranjero y todo en un riguroso presente contemporáneo.

La vida de un brillante abogado y hombre de negocios, Eugenio Reverte, desemboca en un problema fundamental: el tiempo, que tendría que repartir equilibradamente entre la vida (él mismo, sus gustos y aficiones, la familia, etc.) y los negocios, pero que invariablemente dedica a los negocios hasta destruir todo lo demás: es la imagen de hombre atrapado por el trabajo. El triunfo profesional del ejecutivo implica la anulación del hombre y de su familia, porque la situación repercute inmediatamente en las mujeres que lo rodean: la esposa, la hija, la amante. Del hijo no se dice nada, apenas entra en el juego más que como un número.

Estos tres personajes femeninos constituyen tres imágenes de mujer vistas desde la mirada del narrador, pero perfiladas también con grados de autonomía diferentes. La mujer, Alicia, es sólo una construcción logocéntrica de Eugenio: ni la vemos, ni la oímos, sólo sabemos lo que él dice, ve u oye de ella, porque la describe en el recuerdo, o bien cuando asistimos a una situación compartida por los dos, es él quien nos transmite las palabras de ella. Fue siempre un instrumento en la organización de la vida y de la profesión de Eugenio; es la madre de los hijos, es la que organiza la casa, es la acompañante lujosa en los primeros tiempos del despegue económico, es una figura de espaldas cuando pide la separación y es finalmente una figura disminuida y de luto, apoyada en el hijo, en el entierro de su hija. Eugenio dirá de ella que a veces se comporta de un modo inesperado, porque él la tenía situada en la categoría tópica de «mujeres», pero a veces le da una sorpresa: protesta menos de lo que él esperaba, es más comprensiva en ocasiones, se entretiene sola con viajes, exposiciones y conferencias. Eugenio no sabe, y parece que tampoco tiene mucho interés en saber, si Alicia está atrapada por la casa, si tiene otra vida que la que él superficialmente conoce y si tiene otro papel que el de gastar dinero, según le corresponde en los esquemas sociales al uso. La visión que Eugenio tiene de su mujer es tópica, es la «imagen de mujer» que suele 
presentar un narrador masculino que ve sus cadenas en el trabajo y no ve las de su mujer en sus labores caseras; cuando empiezan a distanciarse él no está seguro de la causa: «yo creo que ella fue torpe e intransigente. Por mi parte nunca le presté atención suficiente (...), la veía genéricamente, «las mujeres», como un ser doméstico, que apetece gastar dinero y suspira por deslumbrar a sus amigas» (36).

En resumen, Alicia es la típica «imagen de esposa» de la sociedad opulenta; es una figura patética, que tanto se ha repetido en la sociedad española actual y en la novela masculina. Su función se agota cuando se termina el «proyecto sugestivo de vida en común», es decir, después del matrimonio y la ilusión primera del marido, y después de que ha criado y educado a los hijos; es una mujer insatisfecha que sigue con el marido sólo por los hijos, y efectivamente Alicia plantea el tema del divorcio el día de la petición de mano de Cecilia, porque la función que la sociedad y el hombre le han impuesto respecto a la familia ha concluido.

La hija, Cecilia, es una «imagen de mujer» nueva: la típica niña mimada por su padre, abrumada de regalos y de facilidades, que se cree la reina del mundo y está segura de sí cuando dice y cuando se contradice, que se casa pronto y mal y se separa pronto y mal. Deja oír su voz en diálogo con su padre (con el efecto inhibitorio que le produce su presencia), del que espera todo, como si de un dios se tratase, y descubre su interior en una carta, en forma de comunicación a distancia, sin la presencia del interlocutor, con los detalles más escabrosos de las relaciones con su marido. Es una «imagen de mujer» que no ha cuajado, que es objeto de cuidados y no tiene preparación alguna para la vida: es el objeto del cariño de su padre y con su muerte es el objeto de su castigo. Ella establece su propio código que la conduce al desastre, y se agota en sí misma, sin posibilidad alguna de porvenir. Su figura clama a gritos contra una educación equivocada, la de la juventud actual, que la conduce a la muerte o que simbólicamente lleva a la degradación de la delincuencia en su especie de reencarnación en la terrorista cuya recuperación social dará sentido de nuevo a la vida de Eugenio. La novela no aclara - no quiere hacerlo-si Cecilia se suicida o sufre un accidente motivado por su situación anímica cuando marcha del despacho trastornada, al informarla Pilar, la secretaria, del adulterio de su padre, el dios del que todo lo espera.

Pilar es una figura que conocemos primero a través de Eugenio y luego directamente, porque el resentimiento no puede ser expresado por otro y hay que exponerlo directamente. Recuerda de un modo 
muy directo a Alicia, la protagonista del relato «Un noviazgo», de Carmen Laforet, que es la historia de un resentimiento. Para Eugenio, Pilar es algo a su servicio, un objeto, un mecanismo más del éxito en el despacho, hasta que descubre que es una persona con intereses y sentimientos y establece con ella una relación amorosa, no muy pasional, pues una vez muerta la hija, no vuelve a hablarle, ni se cree en la obligación de hacerlo. Pilar deja oír su resentida voz («yo sé lo que es ser negro»), deja ver su resentimiento en su conducta y en sus reacciones ante la mujer y la hija de su amante. Ella es funcionalmente el motivo que desencadena la tragedia, al contarle a Cecilia las relaciones con su padre. El carácter narrativo-funcional de esta figura de mujer justifica su tratamiento tópico y también que desaparezca del texto en cuanto ha cumplido su papel literario de coordinadora entre padre e hija, pero es también una patética imagen de mujer.

La visión de las tres mujeres pasa siempre por el narrador, por Eugenio, y adquiere relieve en el caso de Cecilia por su manifestación directa en la carta, o en el caso de Pilar por sus propias confesiones, para justificar en ambos casos una funcionalidad en la trama de la novela.

Eugenio, después de la muerte de Cecilia, recorre un infierno en el que pasa una noche rulfiana, la dormida con la madre del mongólico, escenas de fuga o enajenación en el canto gregoriano, en el aniversario de la profesión de una monja, etc., y sólo encuentra salida cuando, en una especie de sustitución de la hija por una joven terrorista o delincuente, se propone dedicarle el tiempo que no dedicó a Cecilia y recuperarla para una vida normal. El objetivo de su vida, la hija, que omitió por falta de tiempo, será ahora cumplido con la joven terrorista a la que intentará sacar de la degeneración y de la sordidez del mundo carcelario.

Más allá de la historia de los personajes, más allá de la trayectoria psicológica de Eugenio, el lector intuye un mundo de relaciones sometidas a un continuo movimiento que buscan un estatus mientras dura el discurso de la novela. La relaciones marido-mujer, jefe-secretaria, padre-hija, forman un esquema de difícil equilibrio: rotas las primeras, buscan su sitio las segundas y destrozan las del padre y su hija, que serán sustituidas por las de abogado-delincuente, entendidas como humanas más que como profesionales.

Y llegamos así al motivo recurrente en las imágenes de mujer diseñadas por M. Portal en las tres novelas que analizamos: Cecilia, la niña mimada, asume su propio fracaso, su ruptura matrimonial a los pocos 
meses de casada: lo cuenta con cierta naturalidad y con alguna vergüenza recurriendo al diálogo directo o a una carta; pero parece que la seguridad que encuentra en su padre es fundamental en su vida, $y$, por ello, no es capaz de asumir la separación de sus padres, la infidelidad del padre hace que su mundo se le venga abajo.

El código que preside la vida de Cecilia y que subyace para explicar su forma de conducta es realmente una exaltación del actuar, es la falta de toda norma ética en la vida y concretamente en las relaciones de pareja; las normas, si existen, son libremente elegidas, quizá con la finalidad de poder disfrutar de lo prohibido, y la vida no parece tener más fin que el hedonista: la vida en común de la pareja es válida si disfrutan y es un error si no produce satisfacciones inmediatas; el alejamiento, el enfrentamiento, la infidelidad, el odio, sustituyen al amor y el desenlace es la separación matrimonial, o la anulación para volver a empezar. Hasta aquí todo está bien, el juego tiene esas alternativas. Pero tal juego no es válido en las relaciones de los padres: el fracaso propio puede ser tolerable, pero el fracaso de esa pareja, que no se ve como hombre-mujer, sino como padre-madre, no se puede soportar, conduce a la desesperación y quizá al suicidio.

Es el mismo planteamiento, visto desde ángulo diferente, de Sara en $A$ tientas y a ciegas, que vive un intenso amor adúltero hasta que tiene la posibilidad de ser madre y rechaza que los hijos sean ilegítimos, por lo que, en su lógica, tiene que volver con el marido; es la misma actitud de la narradora de Pago de traición, que no encuentra problemas para compartir su amor entre el marido y el amante, pero se escandaliza con la misma situación de su madre. Desde unos matices nuevos, la tragedia se repite: Cecilia se enajena al saber que le ocurre a su padre lo mismo que le está ocurriendo a ella; Sara no quiere que sus hijos procedan de un amor adúltero; la narradora sin nombre de Pago de traición, no está de acuerdo con el adulterio de su madre. La lógica interna de las tres novelas es coincidente, y la relación mimética que puedan tener las tres historias ficcionales con las del mundo empírico, carecen de pertinencia en el nivel literario.

¿Qué imágenes de mujer resultan hoy aceptables? ¿Qué código debe presidir su conducta? ¿Puede pensarse en una liberación de la mujer que se traduzca en una ausencia total de normas en el uso de la propia libertad, o es necesario someter esa libertad a la continuación de la especie? Las leyes jurídicas, las costumbres familiares, las normas sociales, daban lugar a unos perfiles de mujer culpable y víctima de adulterio en la novela realista y naturalista, y como ése era el ámbito 
donde se había planteado la desigualdad en el tratamiento jurídico y social del hombre y de la mujer, la novela actual, escrita por hombres o por mujeres, con narrador masculino o femenino, se mueve en el mismo coto cerrado y analiza las posibilidades de unas imágenes de mujer en las que el uso de la libertad sexual pueda dar lugar a reflexiones sobre sus propios límites, o sobre su falta de límites. Pero es curioso que en toda la novela de adulterio, en la que era manifesta la desigualdad de tratamiento para el hombre y para la mujer, jamás se había planteado como un problema de conciencia el comportamiento del hombre, y por el contrario, ahora, al reconocer la misma libertad para la mujer, surgen nuevos desenlaces que obligan a reflexionar sobre la necesidad de señalar límites. En las novelas de $M$. Portal son las relaciones verticales de la familia las que intentan poner límites a las relaciones horizontales de los individuos

Por otra parte, y dentro de este apartado de crítica de «imágenes de mujer» habría que plantear si las imágenes de hombre propuestas por las novelistas actuales gustan o son rechadas por los lectores. ¿Cómo ven los hombres las figuras de hombre diseñadas por mujeres? $\mathrm{Al}$ comienzo de este ensayo advertíamos que era la misma naturaleza del discurso literario lo que impedía lograr una imagen verdadera de mujer, ya que, en el supuesto de que el proceso generador del arte literario tuviese un carácter exclusivamente mimético, no puede ser trasladado al sistema de signos verbal todo el ser real, con sus circunstancias, su tiempo, su espacio y sus relaciones totales; era necesario un proceso selectivo y eran inevitables los «blancos» que harían perder el equilibrio al ser empírico. Ni las imágenes de mujer que habían sido propuestas por hombres, ni las imágenes de mujer que ahora puedan proponer las mujeres alcanzarán la categoría ontológica de "verdaderas» porque son ficcionales y en este ámbito no cabe tal criterio. Lo que sí parece posible es la búsqueda, la experimentación con posibilidades diversas y con anécdotas nuevas que busquen nuevas «imágenes de mujer», y esto es lo que hacen las novelas de M. Portal.

\section{b) Rasgos de kestilo femenino»}

El análisis de «imágenes de mujer» tiene carácter temático y se sitúa en el nivel pragmático, pues trata de contrastar los personajes de ficción con las personas o tipos humanos de la realidad social pretendida- 
mente estable y modélica; de este análisis pasamos a otro más decididamente literario sobre relatos hechos por mujeres para comprobar si los rasgos que se han considerado propios del estilo femenino, lo son realmente. Para ello tendremos en cuenta la composición y disposición de la trama, las unidades sintácticas (funciones, personajes, tiempos y espacios), las formas de discurso (estilo, uso de los deícticos personales, lenguaje interior o exterior, etc.), así como los aspectos semánticos (narrador, visiones, foco), que crean el sentido. Todos ellos están involucrados, pues la elección de unos motivos, exige unas formas determinadas y crea unos sentidos propios, y todos están en relación con el llamado estilo femenino.

Parece haber entre las novelistas una actitud bastante generalizada: rechazar en la sintaxis de sus novelas y en sus formas de discurso la sintaxis tradicional y las formas de discurso de la novela masculina. Es decir, estamos ante la misma situación que se planteaba al comienzo del apartado anterior: la crítica de «imágenes de mujer» se iniciaba con el contraste entre las figuras femeninas en la novela masculina y las ideas que sobre las mujeres tienen las novelistas o críticas femeninas. De aquí que se haya analizado la novela femenina en forma dialéctica con la novela de hombres, y principalmente con la novela decimonónica, considerada como modelo de novela. Aunque en este punto estamos de acuerdo con E. Sábato de que la novela decimonónica es prototipo de novela del siglo XIX, no de toda la novela, pero nos vale el tópico como punto de partida.

En tales análisis contrastivos se ha buscado lo diferencial entre las novelas de los dos sexos y se ha concluido que la novela femenina tiene una voluntad de estilo personal que puede definirse por oposición al estilo masculino y por la concienciación ante una diferencia, que se refiere en primer lugar frente al sexo masculino, pero también frente a otras mujeres: las novelistas, o sus heroínas, se presentan como luchadoras, inconformistas, raras, frente a mujeres, «normales», dóciles frente a la familia y la sociedad, que no ponen en duda el sistema de valores en el que viven.

Los principales rasgos que suelen señalarse como propios de la novela femenina se refieren a los motivos, la construcción, el discurso y el sentido que todos estos elementos adquieren en el conjunto, y serían los siguientes:

a) El realismo social es sustituido por un realismo psicológico (temas). 
b) Las estructuras sintácticas suelen ser más libres (construcción).

c) Hay una tendencia acusada hacia lo informe (construcción).

d) La expresión suele ser menos convencional y menos cuidada (discurso).

e) El interiorismo predomina sobre lo externo (discurso).

f) Es frecuente el relato en primera persona (discurso).

g) El lenguaje suele ser interior (discurso).

h) La novela se estructura fundamentalmente por la «visión», que se convierte en «dominante», y suele ser subjetiva (semántica).

i) El mundo ficcional suele limitarse, o al menos inspirarse, en el mundo empírico de la autora.

Todos estos rasgos, que se localizan en diferentes unidades y aspectos del relato, tienen un origen común y son manifestación de un mismo hecho: la mujer novelista suele escribir sobre su experiencia directa, de modo que más que crear mundo de ficción tiende a presentar o a representar su mundo personal, porque considera que es un ámbito inédito en la literatura. Pero advertimos inmediatamente que no suele limitarse a presentar, sino a representar, es decir, la novelista ficcionaliza la experiencia desde una visión determinada y desde una distancia que suele identificar con una fase de ingenuidad (visión infantil), de descubrimiento (visión adolescente), o visión crítica (de mujer), porque no le interesan las acciones en sí, la aventura o la historia, sino el modo en que la narradora o el personaje femenino las ha vivido. La visión que tienen las mujeres del mundo de la realidad es diferente de la visión masculina y resulta interesante descubrir y dar forma a esas visiones especiales.

La mujer ha tomado conciencia de que ha de escribir para reflexionar sobre su condición, su situación, su actuación y además que ha de hacerlo de un modo propio, porque no está de acuerdo con las figuras de mujer que ofrece la novela masculina ni con el mundo ficcional en que las pone. Las acciones reales o ficcionales, vistas desde dentro, por la protagonistas y desde una visión femenina, constituyen la materia de muchas novelas de mujeres: La plaza del diamante, La calle de las camelias, de M. Rodoreda; Nada, de C. Laforet; Barrio de Maravillas, Memorias de Leticia Valle, de R. Chacel; Bella y oscura, de R. Montero, Nubosidad variable, de C. Martín Gaite, etc., son ejemplos de esta tendencia de la novela femenina. De todos modos hay que decir que 
una cosa es la intención con que se emprende una novela y los medios que se usan para darle forma y otra cosa es lograr que el lector la lea desde esa misma perspectiva. La literatura, como comunicación a distancia y como proceso artístico, presenta las dos caras (creación/recepción), que pueden estar muy distanciadas.

A pesar de que muchas novelas femeninas efectivamente presentan un mundo empírico ficcionalizado por una visión particular, no todas coinciden en el modo de representarlo. E. Showalter (1977) clasifica la escritura femenina en tres tipos: 1) femenina, con obras escritas por mujeres que aceptan la situación y el ordenamiento social y el papel que se les señala; 2) feminista, que presenta mujeres que se declaran rebeldes y polemizan con palabras o con actitudes, y 3) de mujer, que se concentra en el auto-descubrimiento, generalmente de una personalidad «rara», sin pretender un contraste o un enfrentamiento. Showalter se refiere fundamentalmente a la novela inglesa femenina del siglo XIX, pero en cualquier época pueden descubrirse estas tres actitudes y también es frecuente que aparezcan dos o tres en su misma novela. Los tipos puros de novela son escasos, y cuando se habla de caracteres o figuras de mujer aparecen en forma diversa, según los tipos y según las autoras, y lo mismo ocurre con los llamados rasgos de estilo femeninos. Vamos a repasar algunos de los que se señalan como más frecuentes.

El punto de partida es «la toma de conciencia» de la mujer escritora que se considera diferente del hombre y quiere dejar testimonio de su modo de vivir en los acontecimientos que le han sucedido. La toma de conciencia suele propiciar el discurso en primera persona. La autora utiliza la propia experiencia, porque es «verdadera», frente a la construcción imaginaria de la novela masculina, que es «falsa» y, puesto que el discurso se muestra convencionalmente como el efecto de una reflexión y de una visión del mundo nueva y propia, también usa frecuentemente un lenguaje interior. La novelista contrapone su realidad femenina como argumento de verdad frente al mundo ficcional creado por el novelista, y en primer lugar se lo aclara para ella misma, de ahí el lenguaje interior, el de la reflexión. No obstante, a veces, esta misma disposición hacia la propia visión y la experiencia directa la descubrimos bajo un discurso en tercera persona o un lenguaje exterior. No puede identificarse la toma de conciencia, que es una actitud, con una forma determinada de discurso (interior/exterior), o con el uso de una persona gramatical (primera/tercera persona): una cosa es la materia del relato, otra es su forma lingüística. El espejo roto, de M. Rodoreda, es una revisión de vidas de mujer en varias generacio- 
nes, contada en tercera persona por un narrador omnisciente que no se textualiza ni como hombre ni como mujer, aunque da la impresión de que es una narradora, por el interés que muestra por las figuras de mujer, pero no puede interpretarse como autobiográfica, ya que se mantiene en tres generaciones.

En 1929 V. Woolf aseguraba que la era de la autobiografía había pasado y que la mujer ya no escribía para desahogarse o para rebelarse, sino para crear un mundo artístico, como el hombre. Recientemente, Julia Kristeva volverá a insistir en la necesidad de abandonar la forma autobiográfica para alcanzar la madurez creadora. En realidad la madurez se alcanza cuando se puede elegir y cuando la autobiografía no es la única forma de expresión y podemos decir que hace tiempo que no lo es. A pesar de la voz en primera persona, la novela no tiene por qué ser biográfica, y menos autobiográfica, y a pesar del discurso en tercera persona, una novela puede ser biográfica, aunque no autobiográfica. Tampoco es necesario que el narrador sea hombre o mujer, pues todas estas circunstancias son de libre elección de autor o de la autora y la autoconciencia tiene diversas formas de manifestación, no exige una unívocamente.

Aunque las novelas femeninas están escritas en su mayoría en primera persona o tomando como foco único una figura de mujer, esto no implica que sea un rasgo femenino, sino que, aparte la libertad de elección de la autora, puede estar en relación directa con la materia novelada, con modas, o con una determinada visión del mundo en un momento dado de la historia; la experiencia propia representada en una visión personal y revisada críticamente para concienciarse de la propia condición que se siente como diferente de la masculina, suele manifestar en un discurso en primera persona y en un lenguaje interior no dirigido.

En este punto conviene aclarar que la materia narrativa elegida y las formas inmediatas de manifestación locutiva que de ella se derivan no imponen un estilo realista, como pudiera creerse. En la novela, donde prevalece la función estética, no resulta pertinente plantear el problema de la verificación o de la falsación, es decir, si es o no «verdad» lo que allí se cuenta: la «verdad» del lenguaje literario no destruye la distinción entre hechos reales, basados en hechos vividos y hechos ficcionales, inventados por la autora. Para Mukařovski la oposición entre hechos reales y ficcionales es una cuestión de semántica interna a la obra, y no tiene mucho que ver con la cuestión de sus valores referenciales, es decir, el tomar como tema la propia experiencia no exige la 
selección de hechos verídicos, pues puede tratarse de sueños, de mundos imaginarios, etc., que pertenecen a la experiencia psíquica.

El lenguaje interior, en primera persona, es decir, el monólogo interior (dirigido a un alocutario textualizado o no, o simplemente como proceso expresivo, sin alocutario), permite una gran flexibilidad en la composición y en la disposición de los motivos narrativos, puesto que el tiempo psicológico y el espacio mental en que se sitúan las acciones, no tiene condicionamientos, permite asociaciones inesperadas, blancos discursivos y desorden cronológico (analepsias y prolepsias temporales), ubicaciones aparentemente caprichosas, etc. De estas circunstancias deriva una gran libertad narrativa, de modo que una actitud (la autoconcienciación) deriva a una forma lingüística determinada (el discurso de la primera persona y el monólogo interior) y suele traducirse en una mayor libertad en la composición y en la disposición de los motivos, pero cada uno de estos rasgos es independiente, no mantienen entre sí una relación de causalidad. El espejo roto sigue una técnica de articulación de los motivos completamente libre. La narradora omnisciente, en tercera persona, no textualizada, elige, desde la convencionalidad de la historia, cuadros que son fragmentos sin continuidad, que sólo en la lectura total adquieren su lugar y se organizan en su orden. El mismo texto (pág. 304), partiendo del lema, tan conocido, de la novela como un espejo que se pasea a lo largo de un camino, explica cómo la realidad se fragmenta espacial y temporalmente con el espejo roto del recuerdo:

«Del primer piso al vestíbulo bajó la escalera con el especjo enfocado hacia atrás: veía en él retazos del techo, de la barandilla, dibujos y guirnaldas de la alfombra que cubría los peldaños, todo vivo y confuso, hasta que al llegar al último peldaño cayó cuan larga era envuelta en pliegues violeta. El espejo se había roto. Los pedazos seguían dentro del marco, pero algunos había caído fuera. Los iba recogiendo y colocando en los huecos donde le parecía que encajaban, los fragmentos del espejo desnivelados, ¿reflejaban las cosas tal como eran? y de pronto en cada fragmento de espejo vio años de su vida vivida en aquella casa. Fascinada, encogida en el suelo, no lo entendía. Todo pasaba, se detenía, desaparecía. Su mundo tomaba vida allí dentro con todos sus colores, con toda su fuerza. La casa, el parque, las salas, la gente; en la juventud, en la madurez, de cuerpo presente, la llama de los cirios, los niños. Los vestidos, los escotes, las cabezas que sobre ellos reían o demostraban tristeza, los cuellos almidonados, las corbatas con nudos perfectos, los zapatos recién lustrados caminando sobre alfombras o por la arena del jardín. Una orgía de tiempo pasado, lejos, lejos... qué lejos estaba todo... Se puso en pie trastornada, con el espejo en la mano». 
La composición de la novela recoge los pedazos rotos que reflejan escenas de la vida pasada y la disposición los ensarta como cuentas de una historia en el hilo del recuerdo. El lector recoge los pedazos rotos, perfila el ser de los personajes, recompone las relaciones, se detiene en algunas escenas y construye un mundo ficcional poblado de figuras vivas.

Insistimos en que las formas de enunciación del discurso, aunque elegidas por el autor, pueden responder hasta un punto a una exigencia intrínseca del enfoque que se dé a los temas, de las relaciones que mantengan los personajes entre sí, del sentido del tiempo y diríamos que dependen también de la actitud epistemológica que mantenga el autor, porque si cree que no es posible el conocimiento de las intenciones, o que no es posible la comunicación entre los hombres, deberá dotar a sus personajes de palabra y de reflexión interior para que sean ellos quienes manifiesten su punto de vista, sus valoraciones éticas, y den a conocer sus intenciones. Delibes ha dicho que llegó a escribir doscientas páginas de Cinco horas con Mario en un diálogo entre Carmen y Mario, pero no cuajaba la novela hasta que el discurso tomó la forma de monólogo interior dirigido por Carmen a su marido muerto y de cuerpo presente. La comunicación había sido imposible entre el matrimonio y la novela parece expresarse de forma más adecuada en ese monólogo de cinco horas en el que Carmen reflexiona interiormente sobre todo lo que no pudo decirle a Mario vivo.

Cuando se toma conciencia de una situación y se reflexiona sobre ella, aparte de las formas de expresión que se elijan o que se impongan, surge el deseo de encontrar las causas que la han creado, y que suelen presentarse de modo complejo y problemático. La situación de la que se parte es con cierta frecuencia un hecho anómalo, una situación-límite, que ha obligado a la narradora a hacer un alto para reflexionar y la conduce al pasado en busca de los antecedentes objetivos o subjetivos de los conflictos. Para revisar el pasado suele aplicarse alguno de los recursos habituales de flash-back: la memoria interior, algún escrito en forma de diario o de memorias que aparece casualmente, unas confidencias hechas a un amigo que ha estado ausente, o alguna otra estrategia narrativa que permita repasar críticamente los hechos y dar con las claves de la situación presente.

Por estas razones son frecuentes las novelas de memorias que repasan el pasado desde un presente elegido; las Memorias de Leticia Valle pueden servir de ejemplo a esta actitud femenina. S. Beauvoir afirma que las mujeres se dejan llevar más que los hombres hacia las memo- 
rias, pero esto no es una casualidad, hay que situarlo en relación con la actitud general de la novela de mujeres, de reflexión sobre la situación y las experiencias propias y también hay que relacionarlo quizás con un modo de captación y vivencia del tiempo: mientras los hombres cuentan el tiempo por las acciones, las mujeres suelen recordarlo por las emociones que han experimentado.

N. Hartmann ha diferenciado la conciencia intuitiva y la conciencia concipiente: la primera se limita a observar y se atiene a los datos; la conciencia concipiente (discursiva) se pregunta sobre las razones, las relaciones entre los hechos, la necesidad y la posibilidad de las sucesiones (Hartmann, 1960). Nos parece que la conciencia intuitiva se encuentra con mayor frecuencia en la novela femenina, y de ella deriva una forma especial de entender las acciones y de situarlas en el tiempo.

Las condiciones de posibilidad que el presente va creando a medida que se suceden las acciones de unos y de otros personajes se concretan en la sucesión de los hechos futuros. La novela femenina tiende a presentar los datos como una sucesión de hechos vividos intuitivamente, que se magnifican desde el punto de vista de la protagonista narradora, de modo que el lector está siempre a la expectativa de lo que puede venir y que, a medida que va concretándose, no tiene más relieve que lo pasado. En este sentido la lectura de una novela femenina de este tipo crea una frustración continuada en el lector. Las Memorias de Leticia Valle van discurriendo por afanes caseros y diarios mientras la narradora insiste en presentarse como «rara», excepcional y poco menos que predestinada para alguna tragedia; textualmente no pasa nada, pero el lector tiene indicios para pensar en todo.

La novela masculina suele analizar las causas y las condiciones de posibilidad en el presente o en el pasado y explica la historia, además de exponerla. Foster aseguraba que la novela nos tranquiliza porque presenta en forma inteligible una historia cuyas partes y relaciones explica, y esto puede ser cierto en el año 1923 y para la novela masculina, pero no lo es para la novela posterior y desde luego no para la femenina, cuyas asociaciones, y cuya disposición obedece no a la conciencia discursiva, sino a la conciencia intuitiva.

Si analizamos la forma en que se presentan las secuencias de $L a$ plaza del diamante, podemos comprobar que están siempre en un tiempo vivido por la protagonista sin ningún discernimiento: en el discurso cobran el mismo relieve frases que ha oído, acciones que le cambiaron la vida o la condujeron a situaciones difíciles, comentarios al 
hilo de acontecimientos de su vida y de la ajena; todo adquiere el mismo tono narrativo en un proceso de autorreconocimiento intuitivo, que transmite un sentimiento de nostalgia ante el paso del tiempo. La narradora, Natalia-Colometa, adopta ante su vida la visión impasible que tendría una espectadora y ofrece con el mismo tono acciones, palabras, pensamientos suyos y ajenos, por los que pasó «como si fuera de corcho" (así lo dice), porque todo le resbala, sin intentar explicar nada. Su modo casi inconsciente de estar en la vida y la impasibilidad con que se desliza por el tiempo le impide decidir nada; las cosas le van ocurriendo sin que ella las elija, ni intente elegirlas, hasta que toma conciencia de ese distanciamiento y se convierte en narradora, función para la que parece tener más competencia que para la vida.

El seguimiento progresivo de las acciones para aprehender la temporalidad o para explicar su encadenamiento causal por medio de una conciencia discursiva, es sustituido en la novela femenina por la presentación de las emociones que les dan unidad; sólo desde la situación presente la narradora puede repasar críticamente el pasado para rectificar sus emociones. Es la situación por la que atraviesa Ana Ozores cuando recuerda el episodio de la barca y experimenta la indignación que no había sentido cuando ocurrió y que hubiera debido sentir ante lo que sus tías sospechaban y creían; una indignación que no pudo sentir porque no comprendía nada cuando sucedieron los hechos, la sentía ahora y se irritaba retrospectivamente: el recuerdo superpone los sentimientos de Ana en las dos escenas en una síntesis de vivencias, que no dan en ningún caso ocasión para explicar los hechos. Es una escena frecuente en la novela femenina y que en ocasiones sirve de recurso para disponer los motivos en la historia: los hechos recordados que se vivieron intuitivamente y suscitaron un sentimiento determinado, vuelven a matizarse también intuitivamente desde otro sentimiento en la visión actual. El lector se siente un tanto desconcertado en sus hábitos de lectura porque en las novelas femeninas no se cumplen las expectativas que el mismo texto va creando desde un punto de vista lógico, aunque puedan cumplirse desde la intuición.

Hay un tono casi imperceptible en muchas novelas femeninas que, según creemos, puede explicarse desde este supuesto y en relación a la percepción temporal que convencionalmente adopte el discurso. El relato de los hechos, seguido en presente, aunque sea recordado, apunta a un futuro que se ofrece como algo todavía indeterminado, aunque la narradora lo conozca en el momento de la enunciación; frente a la indeterminación e inseguridad del futuro, el pasado está fijo 
e inamovible. Cada uno de los momentos presentes es una «pluralidad de posibilidades» en un horizonte abierto hacia el futuro, que en ellas basa su indeterminación. En cada momento algunas de las posibilidades teóricas están ya desechadas, pues sólo valen las que admitan las condiciones del presente. Esas distintas posibilidades van concretándose en una sola que se realiza a medida que el futuro va convirtiéndose en presente.

Esta situación, que es común a todo lo humano, es percibida de modo bastante diferente por el hombre y por la mujer, porque en la novela masculina el proceso se subordina a la libertad, que no se presenta como una condición más, sino como un poder autárquico, paralelo, cuyo ejercicio elimina el determinismo de los hechos al considerar la intervención libre del sujeto, dentro de las posibilidades y condiciones del tiempo. El horizonte de expectativas es el reino donde el hombre ejerce la libertad. Antes de que ocurran las cosas, y mientras aún es posible darles una u otra realización, actúa la libertad para imponer la deseada, si es posible, en cuyo caso se triunfa, y en caso contrario se fracasa. Pero en la novela de mujeres no suele ocurrir así: las cosas van sucediéndose una tras otra sin que parezca posible el ejercicio de la libertad; el tiempo se abre a posibilidades que se concretan sin que la mujer tome la iniciativa en ningún momento. En La plaza del diamante ocurre así, en Espejo roto ocurre así, en La calle de las camelias, en Nada, ...

En ocasiones se recurre a la novela-río para contar una historia que se prolonga en varias generaciones, siguiendo el presente en sucesividad, puesto que el recuerdo sólo es válido para la propia vida. Aunque las causas de la novela-río se encuentran en las aspiraciones cientifistas del naturalismo, en su intento de verificar la ley de herencia mediante el seguimiento del ser y de la conducta de individuos en varias generaciones, su forma de enlazar diacrónicamente una historia por los miembros de una familia se convierte en un modelo de disposición del relato que se aprovecha, aunque no obedezca a las mismas intenciones.

Novelas con un amplio seguimiento diacrónico, situadas en el marco de unos hechos históricos que señalan el paso del tiempo a la vez que fijan referencias realistas, las encontramos en escritoras como Mercé Rodoreda, Rosa Chacel, Elena Quiroga, Ana María Matute, Dolores Medio, Carmen Martín Gaite, etc., si bien, por lo general, las alusiones históricas se presentan como recursos generadores de realismo, sin que lleguen a constituirse en materia narrativa. 
Es posible que en este punto concreto de manipulación del tiempo y su vivencia pueda señalarse algún contraste de matiz entre la novela masculina y la femenina. En las novelas de memorias y en las novelas río, las novelistas no suelen limitarse, por lo general, a mostrar las secuencias de acciones de una vida, o hacer un seguimiento de los comportamientos psicopáticos o patológicos en varias generaciones, pues su dibujo de una trayectoria vital o su reconstrucción del pasado de varias generaciones de una familia no responde a la intención directa de construir una historia o describir una situación, es decir, no presentan unas acciones encadenadas y unificadas en un relato al que se le da un sentido, sino que la «dominante» para estructurar la novela sigue siendo la visión de la narradora, y el criterio de unidad de las diferentes experiencias es el efecto psíquico que le produjeron; no interesa la acción por la acción, la historia por la historia, sino la forma en que se ha vivido y, sin duda, dos hechos distanciados y sin una relación objetiva en sus extremos, pueden conseguir un mismo efecto en el ánimo de la narradora, y esto es razón suficiente para considerarlos próximos en el relato. Por esto no es de extrañar que algunas novelas femeninas giren en torno a un solo hecho, que se repite, o a una etapa concreta del pasado que fue determinante en la vida de la protagonista. Parece posible relacionar esta actitud con lo que hemos dicho anteriormente sobre el tiempo y su percepción.

Y en todo caso, sea un solo hecho, sea una secuencia o un panorama de hechos cuyos efectos sobre la narradora se intentan esclarecer, ésta los ve desde el presente, y con una actitud intuitiva más que discursiva, removiendo los recuerdos en busca de aquellas situaciones que al suceder entre otras no parecían tener gran relieve y, sin embargo, fueron clave para crear su identidad femenina. Se trata de un proceso de autoconciencia intuitiva, de identificación o búsqueda de la propia identidad y de sus claves emotivas, que lleva a ordenar los hechos por su fin, es decir, no tanto causal como teleológicamente. Y sin duda, los relatos así estructurados tienen un contenido explicativo, y tienen un valor catártico como el que Forster reconoce a la novela que explica y hace comprensibles las historias pasadas, pero se apoyan no en la lógica de las acciones, sino en su dimensión sentimental, intuitiva, inmediata.

Volviendo a La plaza del diamante, Colometa toma la actitud de una observadora distante; ella, según su relato, siempre ha actuado como sujeto pasivo al que van sucediendo cosas: su madre ha muerto, su padre se ha casado otra vez, ella se casa porque lo planea el Quimet, a pesar de que parece tener inclinación por su novio anterior, el Pere, 
asiste al nacimiento de sus hijos, alude a la guerra, a la muerte de su marido, a su segundo matrimonio, como si la llevasen de la mano, pues ni elige ni interviene para decidir algo y nunca toma la iniciativa. El día de la boda de su hija, Colometa reflexiona, quizá por contraste con la nueva generación que parece controlar su destino; sale de madrugada para recorrer los sitios por donde ha pasado tantas veces, compara escenas vividas como en sueños y empieza a sentir la situación presente y el tiempo y el temor de perderlo. La vida consciente y discursiva de Colometa pasa no sólo por un sentimiento del tiempo, que ya lo tenía, sino también por el temor a perderlo, lo cual ya implica una conciencia discursiva sobre las posibilidades hacia el futuro.

La creación y la elección de los motivos (inventio, compositio), su distribución sintáctica en el discurso (dispositio), es decir, la trama y el argumento de la novela, están en estrecha relación con la forma de discurso en primera persona y la visión emotiva del pasado desde la perspectiva del presente en que la novelista repasa su vida y toma conciencia de su modo de estar en el mundo.

Esto no quiere decir que las novelistas no tengan más temas que los derivados de su propia experiencia intuitiva, y esto a pesar de que en muchos casos sea cierto. Se trata de una convención por la que asumen como propia la experiencia ficcional de sus protagonistas presentándola como una autobiografía, o convierten en ficción su propia experiencia vital, siempre desde la perspectiva de la intuición. El tema posterior consiste en situar en un tiempo y un espacio narrativos esa materia y tales visiones, bajo el discurso que sea (en primera o en tercera, interior o exterior).

Respecto a la visión y al tiempo, es importante determinar dónde se sitúa el "presente» de la enunciación, porque es muy diferente narrativamente que se vayan viviendo los hechos, es decir, que se elija el presente narrativo que pone como simultáneos la enunciación y el enunciado, a que los hechos sean recordados y se sitúen en el pasado. La narradora puede ser una mujer que revive su pasado, una adolescente que se encuentra desconcertada con el descubrimiento de la vida y empieza a ver las cosas, o una niña que cuenta sorprendida lo que observa sin entenderlo; en los tres supuestos el tono que exige el lenguaje es bien diferente y las referencias de la narradora condicionan las interpretaciones en relación al límite que elija para el relato.

Ciplijaikausté (1988) señala que la concienciación se consigue de varios modos, que son otras tantas posibilidades de acotar el tiempo de la enunciación desde el desenlace de los hechos (historia pasada cuyas 
escenas se seleccionan para reflexionar), en simultaneidad con los hechos (exige discreción suficiente para valorar el presente sin la perspectiva del tiempo), es decir, contar los hechos mientras se viven, o contarlos con la ayuda de la recreación de la memoria. Cada una de estas formas, como procesos semióticos diversos, implica la creación de un sentido que se añade a la significación que pueda tener la historia, y es, por tanto, una manipulación semántica. Contar en presente implica dar prevalencia a las acciones, observar, no seleccionar; contar en el pasado supone seleccionar, reflexionar sobre las condiciones de posibilidad en el futuro y sus consecuencias, interpretar desde una posición adoptada de rebeldía, de crítica, de rechazo, etc., superponiendo dos situaciones anímicas, la del pasado y la del presente.

H. Bergson (1899), en su intento de penetrar en el núcleo de la conciencia no conceptual, ha explicado que la memoria permite aclarar las distintas fases por las que atraviesa la conciencia, y permite diferenciar el hacer y lo hecho, el devenir y el resultado y, por tanto, permite enfrentar críticamente el presente que se vive y el pasado que se recuerda. La revisión del pasado que proporciona la memoria, da lugar a un desdoblamiento de la persona que se objetiva a sí misma para juzgarse en otro tiempo y para descubrir la lógica de los hechos: las relaciones de causalidad, lo mismo que las relaciones psíquicas de dos escenas a través de un sujeto, quedan claras al eliminar los ruidos no significativos de la historia y esto sólo puede hacerse desde el desenlace. Por otra parte, el continuo fluir de la conciencia y la evolución creadora de la mente se perciben mediante la intuición, que, según creencia muy generalizada, es cualidad preferentemente femenina.

Algunas narradoras, fijadas en el presente como observadoras, revisan el pasado como críticas, se mueven en el tiempo por medio de la memoria y construyen el relato mediante la técnica de un intermitente flash-back, lo que da lugar a un tipo de composición altamente selectiva y a una especial disposición que sitúa los motivos en un orden que no es precisamente el cronológico. La forma de discurso que se impone en estos casos es el monólogo interior, que es la expresión más adecuada para el recuerdo y la disposición del relato tiene la apariencia de un desorden total, justificado por la falta de un mundo empírico, objetivo y su sustitución por un mundo subjetivo.

Las dos posibilidades (vida-recuerdo: presente/pasado), con las variantes señaladas, son las más frecuentes en la novela femenina, pero no son únicas. A veces la narradora permanece quieta en el tiempo para presentar cuadros, espacial y temporalmente fijados, siguiendo 
una técnica de camera eye. De este modo puede ofrecer también, a través del recurso cinematográfico del montaje, una visión múltiple de la realidad presente o pasada, puede poner en contraste dos situaciones distantes, puede tomar como motivos recurrentes aquellos que para la finalidad que les señala el relato tienen un mismo sentido, aunque tengan formas diversas, o situando en contigüidad escenas que en el mundo empírico están distantes.

La novela femenina, como la novela masculina, puede organizarse de múltiples maneras: la vida interior se suma a la vida exterior, el pasado se suma al presente, la acción se somete a la reflexión, el orden temporal de las acciones se sustituye por el desorden psíquico de las vivencias, la percepción de imágenes inmediatas con grados de luz diversos es acompañada de comprensión de varias imágenes superpuestas que sugieren o son metáforas... Cada autor elige sus temas y les da las formas que más se adaptan a ellos, y parece que las mujeres se inclinan por formas preferentemente relacionadas con la conciencia intuitiva con que suelen enfrentarse a la vida.

Algunas novelas femeninas son relatos que buscan las causas del presente en el pasado, pero no necesariamente un esquema causal objetivo, sino un esquema subjetivo cuya comprensión proceda de una especial visión de las cosas, o que se apoye en el contraste de dos formas de percepción; e intentan fijar el puesto que corresponde a la protagonista y aclarar su forma de estar en el conjunto familiar o social.

Este tema hay que relacionarlo con el llamado desorden de la novela femenina. Hay desorden porque se les aplica un criterio cronológico y las acciones se adelantan o se atrasan aparentemente a capricho, pero si se aplica un criterio ordenador de tipo psíquico, no hay tal desorden.

A diferencia de la llamada «novela de aprendizaje» (Bildungsroman), la novela femenina de concienciación no suele seguir la trayectoria formativa de la protagonista, en cuyo caso tendría que seguir su trayectoria vital con el orden cronológico en que sucede; por el contrario suele presentar a la narradora-protagonista como una mujer ya formada y con una capacidad crítica, y es su mirada la que repasa la historia y revive los hechos desde un determinado tiempo presente, a partir de alguna circunstancia inesperada, de una situación-límite generalmente, que obliga a buscar las razones de lo que ha ocurrido. La novela femenina no suele ser novela de aprendizaje, sino de autoconciencia o autoconocimiento: es generalmente un intento de explicar cómo se ha llegado, y en la forma que se está, al presente. 
La novela de aprendizaje puede entenderse en dos formas, aunque generalmente se ha seguido sólo una para justificar la denominación. Se puede seguir la trayectoria vital del personaje desde la ignorancia hasta la sabiduría (historia de un aprendizaje), o se puede presentar la historia de un personaje, que aprende o no, pero se ofrece como ejemplo para el lector o lectora, en forma positiva o en forma negativa: la novela es ejemplo de lo que debe hacerse, si se está de acuerdo con la trayectoria seguida por el personaje, o es ejemplo de lo que no debe hacerse, si no se está de acuerdo con el personaje y el desenlace de la historia. En este sentido puede decirse que la novela es siempre novela de aprendizaje.

En razón del fin que pretende, la narradora de la novela de concienciación en primera persona y con lenguaje interior, adopta, si lo estima oportuno, una actitud selectiva de los hechos que ordena según su sentido (el pretendido desorden) e introduce blancos en la historia, y ha hecho algo más importante: desligarse de la ordenación del mundo histórico, que parece una tendencia típicamente masculina desde que Dilthey reflexionó sobre las posibilidades de poner orden, aunque sólo sea cronológico, en el caos del acontecer para lograr una mejor comprensión del mundo. La novelista, en general, prefiere prescindir del orden cronológico y moverse libremente por el pasado, siguiendo las asociaciones que su mente, su intuición, o sus vivencias le sugieran en cada momento, y siempre desde la perspectiva de un desenlace que se caracteriza por ser una toma de conciencia sobre la condición, el ser o el estar de las mujeres en la familia, en la sociedad, en el mundo.

La novela espacial, de cuadros en simultaneidad, al seguir la técnica camera eye, permite también una selección de hechos simultáneos, y puede tener el mismo sentido, pues en una visión panorámica del conjunto de una sociedad, destaca a un primer plano, mediante una iluminación especial (por ejemplo, repetirlos, o ponerlos con mayúsculas, con comillas, etc., como hace A. M. Matute en La trampa), los ángulos, las relaciones, las situaciones, que intuitivamente interesan para el relato en relación con su valor para la autoconciencia de la narradora, o en el proceso de comunicación literaria para el lector. Los primeros planos que se presentan son una manipulación de la realidad narrada, pues adquieren mayor importancia en el conjunto y su sentido predomina sobre otros cuadros que quedan en un segundo plano. Y siempre el criterio para dar el relieve adecuado está en una valoración intuitiva no discursiva o explicativa en la lógica de las acciones. 
Podemos decir que todos los rasgos enumerados y explicados hasta ahora obedecen a una misma causa: la tendencia femenina al discurso autobiográfico, de experiencia directa, total o parcial, que lleva a la subjetividad y al lenguaje interior y en primera persona, a la recreación del pasado por medio de la memoria, a la búsqueda de las claves de la personalidad propia, y lógicamente al uso del monólogo interior (libre o dirigido), y desde este tipo de expresión del discurso a la libre asociación de motivos, que efectivamente se encuentra en muchos - no en todos - los relatos femeninos. Sobre estos hechos, que son rasgos de frecuencia, no específicos en la novela femenina, se han formulado muchos tópicos y se han hecho generalizaciones quizá excesivas acerca de los «rasgos femeninos» de la novela, que difícilmente se pueden mantener como tales si se conoce el panorama de la novela y la evolución de sus formas en la segunda mitad del siglo XX.

Algunas de las técnicas que se dan como propias del estilo femenino se han tomado del cine y las encontramos, junto a otras, en toda la novela moderna; los críticos - hombres o mujeres- que las consideran «femeninas» las presentan reductivamente, puesto que aparecen en toda la novela actual, que ha cambiado su orientación de los acontecimientos exteriores hacia el mundo interior del hombre.

El monólogo interior y la focalización interna, que como hechos del lenguaje se incorporaron pronto al discurso narrativo, son técnicas de construcción de la novela decimonónica que usan autores como Dostoievski, Stendhal, Galdós, Clarín, etc., y que se adapta perfectamente a un concepto dinámico del conocimiento y del acontecer; y se han hecho más frecuentes para estructurar los relatos a partir del Ulises de J. Joyce (apareció como folletín en 1918, estuvo prohibida hasta 1933 en que un juez neoyorkino levantó la prohibición y en 1934 aparece la primera edición norteamericana); es un recurso que aparece casi en simultaneidad en otros autores sin una relación genética precisa, quizá porque es una idea que está en el ambiente y en el conocimiento social después de los estudios de W. James. Problamente su uso práctico en la novela, a partir de su difusión teórica, se debe sobre todo, a que era el medio adecuado para expresar la visión del mundo que se impone progresivamente en el siglo $\mathrm{XX}$, después de los excesos del positivismo.

Una vez que se elige el monólogo interior como forma de expresión, se incorporan al discurso, casi como un efecto inevitable, un especial sentido del tiempo (tiempo subjetivo), unas posibilidades amplias de relación entre objetos, situaciones y anécdotas (asociación libre) y 
unas formas lingüísticas más flexibles (que pueden llegar a la incorrección, al uso de anacolutos, de medias palabras, incluso a la falta de sentido, etc.), pues convencionalmente no es un lenguaje dirigido a un interlocutor, sino un simple ejercicio verbal del mismo emisor, y cumple su función expresiva o acaso aclarativa para el mismo narrador, que se entiende con medias palabras.

Las teorías de W. James (1890) sobre la actividad de la conciencia humana como un continuo fluir (stream of consciousness); el conocimiento concebido también como un continuum y el sentido dinámico del acontecer, son ideas que hacer revisar en la novela las formas de presentación de personajes y de historias y las formas de organización del discurso. La novela suele acusar de modo indirecto las concepciones filosóficas sobre el conocimiento, o las ideas científicas sobre la conducta y la interacción social, de modo que cuando la teoría del conocimiento admite la posibilidad de llegar hasta las cosas y de penetrar en el interior de los sujetos, la novela actúa con sus personajes como si fuesen entidades transparentes, a cuyo interior se acceden mediante la observación y la descripción de su superficie; a una filosofía de las esencias corresponde una novela de narrador omnisciente, de gran seguridad en la historia, que narra en la objetividad de la tercera persona, en un discurso detallado y de desenlace cerrado, puesto que todo queda claro al final y, por el contrario, a una posición escéptica en cuanto a las posibilidades del conocimiento humano, corresponde una forma de novelar perspectivística, subjetivista, de superficie, en la que el narrador desciende del olimpo del conocimiento absoluto y se sitúa en la figura y límites de una persona y se limita a sus capacidades humanas para la observación, para el conocimiento, para el dominio de los medios expresivos.

Las teorías de James sobre el dinamismo de la conciencia; las teorías freudianas sobre la personalidad y la actividad del inconsciente; la aparición de técnicas cinematográficas, como el flash-back, o camera eye, el montaje, etc., ofrecen la posibilidad de dar cuenta de la conducta desde perspectivas interiores y exteriores nuevas, de dar testimonio del pasado y de recoger observaciones sobre la realidad circundante sin otra manipulación que la que procede del punto de vista en que se sitúe el narrador, y afectan profundamente a la novela y sus técnicas en el siglo Xx. La novela femenina puede elegir dentro de la misma variedad de recursos que la masculina, sin duda, y parece inclinarse al discurso de forma autobiográfica, al monólogo interior, a la experiencia intuitiva, al desorden y a la asociación libre. 
La corriente de conciencia está presente en la mayoría de las novelas del siglo actual, en mayor o menor medida, y en relación con esta técnica se sitúan recursos que afectan a la composición y a la disposición de los motivos en la historia narrada, como la asociación libre, el montaje, el salto en el tiempo a través de los recursos, el dominio del subjetivismo en la visión, el discurso de apariencia caótica, con frases sin terminar, con incorrecciones, etc.

Las nuevas posibilidades y recursos narrativos han sido incorporados a las novelas femeninas, pero no podemos admitir que sean originales, ni siquiera característicos, porque no los usan en forma exclusiva, por lo que no puede hablarse del carácter específico de ninguno de ellos. Acaso podríamos hablar en algún caso de índices de frecuencia, de tendencias y preferencias en los relatos de hombres y de mujeres. Para ello será necesario analizar, comparar, y llegar a una base de datos sólida, a partir de lecturas y de estudios contrastivos amplios.

\section{Referencias bibliográficas}

Abel, E. Hirsch, M., y Langland, E. (ed.). (1993). The Voyage In: Fictions of Female Development. Hannover/London: U.P. of New England.

ACOSTA DE Hess, J. (1988). Galdós y la novela de adulterio. Madrid: Pliegos. Armstrong, J. (1976). The Novel of Adultery. London: MacMillan.

Beauvorr, S. de. (1949). El segundo sexo. Buenos Aires: Siglo XXI, 1972.

BERgSON, H. (1899). La risa. Ensayo sobre el significado de lo cómico. Ed. del Centenario.

Brown, Ch., y Olson, K. (eds.) (1978). Feminist Criticism. Essays on Theory, Poetry and Prose. Metuchen: Scarcecrow Press.

Brown, J. (1991). Women Writers of Contemporary Spain. New Jersey: Associated University Presses.

BURUNAT, S. (1980). El monólogo interior como forma narrativa en la novela española (1940-1975). Madrid: Porrúa Turanzas.

Calvo Aguilar, I. (1954). Antología biográfica de escritoras españolas. Madrid: Biblioteca Nueva.

CHACEL, R. (1993). Barrio de maravillas. Barcelona: Plaza y Janés.

- (1993). Memorias de Leticia Valle. Barcelona: Lumen, $3^{\mathrm{a}}$ ed.

CiplijauskaitÉ, B. (1984). La mujer insatisfecha. El adulterio en la novela realista. Barcelona: Edhasa.

- (1988). La novela femenina contemporánea (1970-1985). Hacia una tipología de la narración en primera persona. Barcelona: Anthropos.

Cornillon, S. K. (ed.), (1972). Images of Women in Fiction: Feminist Perspectives. Bowling Green, Ohio: B.G.U.P. 
DEMORIS, R. (1975). Le Roman à la première personne. París: Colin.

DIDIER, B. (1981). L'Écriture-femme. París: PUF.

DOLEŽEL, L. (1973). Narrative Modesin Czech Literature. Toronto: U.T.P.

Eagleton, M. (ed.) (1986). Feminist Literary Theory. A Reader. Oxford: Blackwell.

Freedman, R. (1963). La novela lírica. H. Hesse, A. Gide y V. Woolf. Barcelona: Barral, 1972.

FrIEDAN, B. (1963). Mistica de la Feminidad. Madrid: Júcar, 1974.

Galerstein, C. (ed.) (1986). Women Writers of Spain. An Annotated Biobibliographical Guide. Westport, Conn.: Greenwood Press.

Gilvert, S., and Gubar, S. (1979). The Madwoman in the Attic. The Woman Writer and The Nineteenth Century Literary Imagination. New Haven: Yale U.P.

Gullón, R. (1984). La novela lírica. Madrid: Cátedra.

GuERRA-CUnNingham, L. (1980). La narrativa de María Luisa Bombal: una visión de la existencia femenina. Madrid: Playor.

Hartmann, N. (1934, 1937, 1939, 1950, 1954). Antología. Cinco tomos. México: F.C.E., 1954, 1956, 1959, 1960, 1964.

Heilbrum, C. G., and Higonnet, M. R. (eds.) (1983). The Representation of Women in Fiction. Baltimore/London: Johns Hopkins U.P.

IRIGARAY, L (1977). Ese sexo que no es uno. Madrid: Saltés, 1982.

JAMES, W. (1890). The Principles of Psychology. New York: H. Holt.

JEHLEN, M. (1981). «Archimedes and the paradox of feminist criticism». Signs 6/4, 575-601.

JONES, M. E. W. (1983). «Del compromiso al egoísmo: la metamorfosis de la protagonista en la novelística femenina de la postguerra». En PÉREZ, J. W. (1983), 125-134.

Kofman, S. (1980). El enigma de la mujer. Barcelona: Gedisa, 1982.

KolodNy, A. (1975). «Some notes on defining a "feminist literary criticism"». Criticical Inquiry 2/1, 75-92.

LAFORET, C. (1945). Nada. Barcelona: Destino.

López CORDON, M. V. (1982). «La situación de la mujer a finales del Antiguo Régimen (1760-1860)». En Mujer y sociedad en España (1700-1975), 47107. Ministerio de Cultura: Dirección Gral. de Juventud y Promoción Socio-cultural.

MARSÁ VANCELlS, P. (1987). La mujer en la literatura. Madrid: Torremozas.

Martín Gaite, C. (1987). Desde la ventana. Madrid: Espasa-Calpe.

- (1992). Nubosidad variable. Barcelona: Anagrama, 1993, 10. ${ }^{\mathrm{a}} \mathrm{ed}$.

Matute, A. M. (1969). La trampa. Barcelona: Destino.

Mrllet, K. (1970). Sexual Politics. New York: Doubleday.

MoI, T. (1988). Teoría literaria feminista. Madrid: Cátedra. 1988. (Orig. Sexual/Textual Politics: Feminist Literary Theory. Methuen).

MoERs, E. (1976). Literary Women. The Great Writers. New York: Doubleday.

NaSH, M. (1983). Mujer, familia y trabajo en España, 1875-1936. Barcelona: Anthropos.

NeLKEN, M. (1930). Las escritoras españolas. Barcelona: Labor.

NiEva DE LA PAZ, P. (1992). «Tradición y vanguardia en las autoras teatrales de pre-guerra: Pilar Millán y Halma Angélico». En El teatro en España entre la tradición y la vanguardia (1918-1939), Dougherty, D., y Vilches de Frutos, M. F. (eds.), 429-438, Madrid: CSIC, Fundación García Lorca. (Incluye también otros artículos sobre mujeres dramaturgas, Concha Mén- 
dez Cuesta y Pura Maórtua de Ucelay, de E. Miró y M. Ucelay).

- (1993). «El teatro de las escritoras españolas de entreguerras: índice de estrenos y catálogo de textos (1918-1936)». Anales de Literatura española contemporánea 18/3, 693-737.

O'Connor, P. (1987). Gregorio y María Martínez Sierra. Crónica de una colaboración. Madrid: La Avispa.

- (1988). Dramaturgas españolas de hoy. Madrid: Fundamentos.

OrdóñeZ, E. J. (1991). Voices of Their Own. Contemporary Spanish Narrative by Women. Lewisburg: Associated University Presses.

Ortiz APONTE, S. (1971). Las mujeres de «Clarín». Esperpentos y Camafeos. Puerto Rico: Universidad de Puerto Rico.

Pérez, J. W. (ed.) (1983). Novelistas femeninas de la postguerra española. Madrid: Porrúa Turanzas.

- (1988), Contemporary Women Writers of Spain. Boston: Twayne Publishers.

PORTAL, M. (1966). A tientas y a ciegas. Barcelona: Planeta.

- (1983). Pago de traición. Barcelona: Planeta.

- (1993). El ángel caído. Bacelona: Planeta.

PratT, A. (1981). Archetypal Patterns in Women's Fiction. Bloomington: Indiana U.P.

QUIROGA, E. (1955). La careta. Barcelona: Noguer.

RodoredA, M. (1962). La plaza del diamante. Barcelona: Edhasa, 1982.

- (1974). Espejo roto. Barcelona: Seix Barral, 3. ${ }^{a}$ ed., 1991.

- (1986). La calle de las camelias. Barcelona: Edhasa, 1989.

- (1991): Isabel y María. Barcelona: Seix Barral.

Rodríguez PuÉRTolas, J. (1975). Galdós: Burguesía y revolución. Madrid: Turner.

RousseT, J. (1973). Narcisse romancier. Essai sur la première personne dans le roman. París: Corti.

SAU, V. (1981). Un diccionario ideológico feminista. Barcelona: Icaria.

SCANLON, G. (1976). La polémica feminista en la España contemporánea (1868-1974). Madrid: Siglo XXI.

Showalter, E. (1977). A Literature of Their Own. British Women Novelist from Brönte to Lessing. Princeton: P.U.P.

- (1979). «Toward a feminist poetics», En Women Writing and Writing about Women, Jacobus, M. (ed.), 22-41. London: Croom Helm.

- (1981). «Feminist criticism in the wilderness». Critical Inquiry 8/1, 179-205.

Simón Palmer, M. C. (1991). Escritoras españolas del siglo XIX. Manual biobibliográfico. Madrid: Castalia.

SCHYFTER, S. E. (1982). «La loca, la tonta, la literata: Woman's destiny in Clarín "La Regenta"». En Theory and Practice of Feminist Literary Criticism, 229-241. Ypsilanti: Michigan Bilingual Press.

TANner, T. (1979). Adultery in the Novel, Contract and Transgresion. Baltimore: John Hopkins U.P.

VoDICKA, F. (1948). Los inicios de la prosa artística checa. Praga: Melantrich. 